\title{
Research Square \\ Impact of rainfall variability on soybean yields in Southern Brazil
}

Felipe Gustavo Pilau ( $\nabla$ fgpilau@usp.br)

Universidade de Sao Paulo https://orcid.org/0000-0003-1370-5352

\section{Fabio Ricardo Marin}

Universidade de Sao Paulo

Daniel Grubert

Universidade de Sao Paulo

Genei Antonio Dalmago

Embrapa Trigo

\section{Research Article}

Keywords: soy bean, yield, rainfall, soil type, Brazil

Posted Date: February 11th, 2021

DOI: https://doi.org/10.21203/rs.3.rs-160366/v1

License: (9) This work is licensed under a Creative Commons Attribution 4.0 International License. Read Full License 
Impact of rainfall variability on soybean yields in Southern Brazil

Felipe Gustavo Pilau ${ }^{1}$; Fabio Ricardo Marin ${ }^{1}$; Daniel Alves da Veiga Grubert ${ }^{1}$; Genei Antonio

$$
\text { Dalmago }^{2}
$$

Corresponding author: Felipe Gustavo Pilau. fgpilau@usp.br

${ }^{1}$ University of São Paulo, "Luiz de Queiroz" College of Agriculture, Biosystems Engineering Department. Av. Pádua Dias, 11. Piracicaba/SP - Brazil. 13418-900

${ }^{2}$ Embrapa Trigo. Rodovia BR-285, Km 294 Caixa Postal: 3081. Passo Fundo/RS - Brazil. 99050970

\section{Abstract}

As the third soybean-producer state in Brazil, Rio Grande do Sul (RS) presents a known year-on-year unevenness for soybean production, mainly due to water availability. This study aimed to assess the weather effects, with special focus on rainfall during 25 soybean growing seasons and 11 producing regions around the State. Sites were divided into three Clusters according to soybean yield and the effect of El Niño Southern Oscillation (ENSO) was considered in association with soil water balance. Neutral ENSO phases occurred in $32 \%$ of the years, while El Niño and La Ninã occurring in $36 \%$ and $32 \%$ of the years, respectively. Seasons under El Niño normally present higher accumulated rainfall, whereas those under La Niña present a reduction. Data from neutralyear sites of Clusters B and C seems to be more disturbed. No season had statistical difference of rainfall among Clusters under Neutral conditions. In addition, thermal gradient in RS from October to January benefited sites of Cluster A. Interaction of soils with higher water-storage capacity and cooler temperature reduces the water consumption by soybeans, causing lower values of water deficiency. A boundary function relating soybean yield and rainfall displays the limit of $800 \mathrm{~mm}$ for significant yield increments, and such amounts of rainfall were only achieved in El Niño seasons. The combined effect of rainfall and soil type on soybean yield, represented by the actual soybean yields-water deficit relationship, led to water propitiate from -3.7 to $-15.2 \mathrm{~kg} \mathrm{~mm}^{-1} \mathrm{ha}^{-1}$. Decisionmaking on public policies and investments on the soybean industry can be supported from our results, either to better planning the investments on the soybean farming systems depending on the ENSO phase predictions, either to reduce the production risks in the region inherent to local weather.

\section{Introduction}

Brazil is the second main soybean producer worldwide, producing 119.3 million tons from 35 million hectares in the 2017/18 season (Conab 2018). The southernmost State of Brazil, Rio Grande do Sul (RS) ranks third among soybean-producer states, with $14.4 \%$ of Brazilian production 
(Conab 2018). Although RS offers climate suitability for soybean crop, the state presents significant inter-annual production variability (Cunha et al. 1998; Battisti et al. 2013).

According to Brazilian National Supply Company (Conab, 2019), the average on-farm soybean yields of the last ten crop seasons ranged from 1.55 to $3.32 \mathrm{Mg} \mathrm{ha}^{-1}$. Considering all Brazilian historical dataset, since 1976/77, the soybean yield variability is even higher, reaching values below 1.0 $\mathrm{Mg} \mathrm{ha}^{-1}$ in three seasons, $0.91 \mathrm{Mg} \mathrm{ha}^{-1}$ (1978/79), 0.72 $\mathrm{Mg} \mathrm{ha}^{-1}$ (1990/91) and 0.69 $\mathrm{Mg} \mathrm{ha}^{-1}(2004 / 05)$.

In such region soybean yield is heavily controlled by farming systems technology but it is also well-known that the irregular distribution of rainfall during the soybean growing season presents itself as a limiting factor to the potential yield of the crop (Berlato \& Fontana, 1999; Sentelhas et al., 2015; Zanon et al., 2016).

Several studies have demonstrated the teleconnections between ENSO and anomalies in the seasonal rainfall patterns in subtropical southeastern South America (Grimm, 2004; Grimm and Tedeschi, 2009; Tedeschi et al., 2015), influencing the spring-summer harvest in RS, especially soybean crop. ENSO is a coupled ocean-atmosphere phenomenon characterized by sea surface temperature anomalies in the equatorial Pacific Ocean (Philander, 1983). Its warm phase called El Niño is associated to some positive precipitation anomalies observed in RS, while the ENSO cold phase is called La Niña, which triggers negative anomalies in the state (Grimm, 2000; Berlato \& Fontana, 2003; Grimm, 2004; Gelcer et al., 2013; Tedeschi et al. 2015; Nóia Júnior et al. 2020).

Based on long-term data of 28 weather stations in RS, Matzenauer et al. (2017) offers a recent analysis about ENSO influence on weather of RS. The average annual rainfall for El Niño (EL) years as equal to $1,858 \mathrm{~mm}$ (occurring in $26.8 \%$ of the years), and being $1,529 \mathrm{~mm}(49.2 \%$ of the years) and 1,480 $\mathrm{mm}$ (24\% of the years) for Neutral and La Niña averages, respectively. Certainly ENSO's influence is geographically different within the state (Gelcer et al., 2013), depending directly on the ENSO intensity/type (Grimm, 2000; Grimm, 2004), and such spatial variability makes the overall impacts of ENSO on soybean yields still uncertain in such region (Berlato \& Fontana, 1999; Matzenauer et al. 2018).

To better understand the relationship between climatic variability and agricultural productivity (Berlato and Fontana, 2003; Arsego et al. 2018) and provide some support, analyzes based on drought or seasonal water indexes (Gelcer et al., 2013; Cordeiro et al., 2018), crop modelling (Fraisse et al., 2008; Nóia Júnior and Sentelhas, 2019; Nóia Júnior et al., 2020) or boundary functions derived from field-year observation (van Ittersum et al. 2013) can help to provide assessments of water-limited yield potential ( $\mathrm{Yw}$ ) and also to inform about technology adoption effect (Grassini et al. 2014; Zanon et al. 2016). 
To our knowledge, the relationship between weather variability to soybean yields in the region is not yet well defined. To fill the gap in the knowledge about the effect of ENSO and weather variability on soybean yield in RS State, and provide some forecast insights for decisionmakers and growers, we analyzed a long-term weather database containing data from 11 weather stations together with the ENSO phases. Specific objectives were: (i) to split the effects of soil and weather on crop yields based on crop modeling simulations and actual yield data (ii) to assess the soybean potential yields and yield gaps for different rainfall levels and regions and (iii) to evaluate soybean crop yield loss due to water deficit in each region of RS.

\section{Materials and methods}

\section{Study area and weather and soil conditions}

For eleven sites from Rio Grande do Sul (Figure 1) data about yield and weather, also correlated with ENSO, were used to analyze soybean yield variability. The Brazilian official dataset of soybean yield is supplied since 1990 by the National Institute of Geography and Statistics (IBGE), and the weather data are provided by the National Institute of Meteorology (INMET) and the State Foundation for Agricultural Research (FEPAGRO) from 1991 to 2017. The climate in RS (Figure 1) is subtropical humid with well distributed annual rainfall between 1,220 $\mathrm{mm}$ to 1,350 $\mathrm{mm}$.
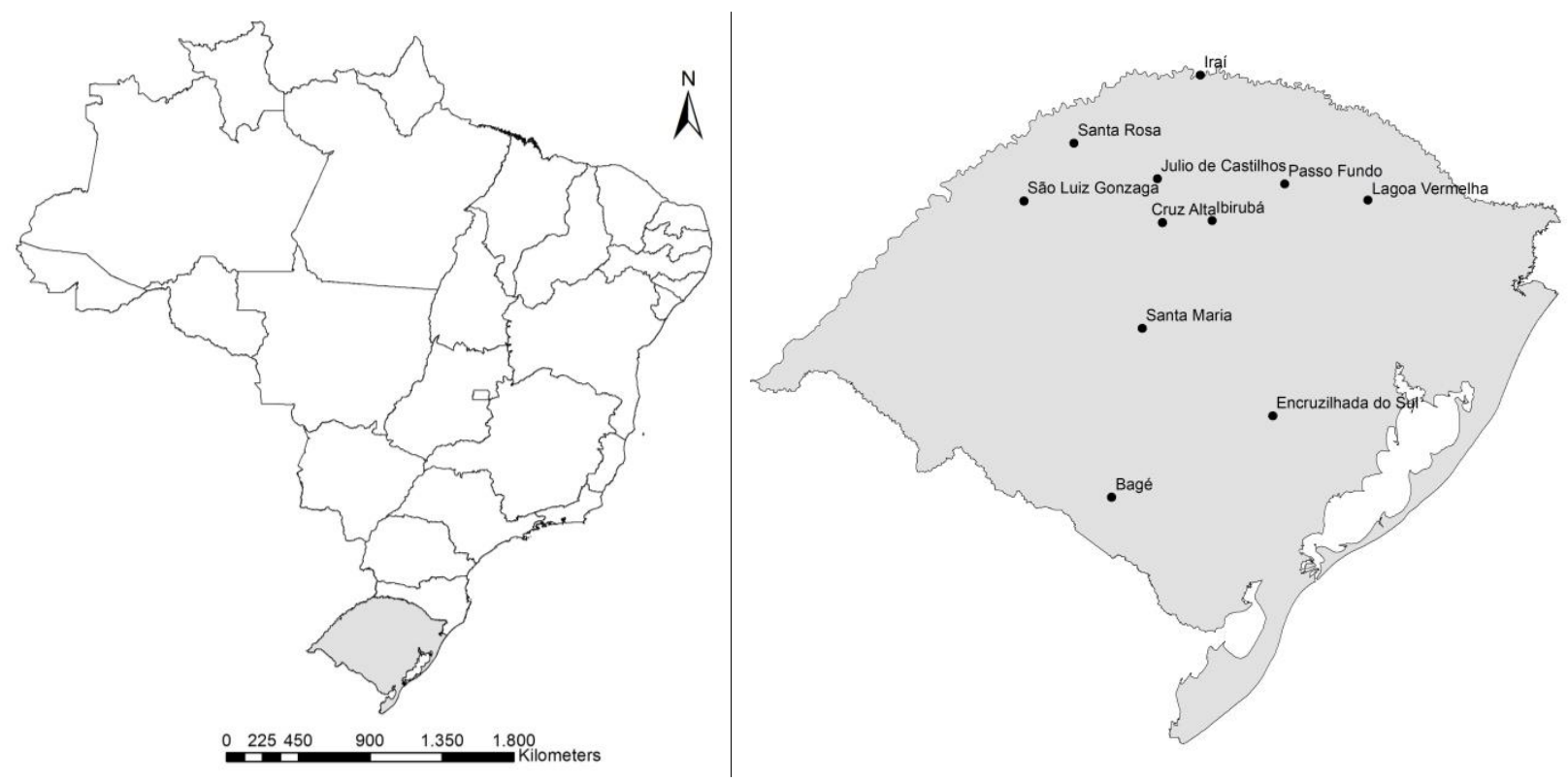

Figure 1. Location of the State of Rio Grande do Sul - Brazil, and distribution of weather stations considered in the analyzes within the State. 
Rainfall missing data were replaced by data from the closest weather station. Air temperature missing data was replaced from linear relationships between the values from nearby stations. Validation methods were applied to identify erroneous data from weather sensors measurements (Estévez et al. 2011). The analyses were based on three classes of consistency tests: range test, step test and internal consistency test (Table 1). The quality of the weather data was examined searching for outliers when compared to other years and to those observed in neighboring stations. By visual inspection, we did not find any outliers after the statistical tests showed in Table 1 were applied to the datasets. Therefore, based on climatic regions of the State of Rio Grande do Sul as defined (Maluf \& Caiaffo 2001) and the homogeneous climate zones provided by van Wart et al. (2013), the weather network density used in the present study provided a properly coverage for the State of Rio Grande do Sul.

Table 1. Quality control procedures applied to Rio Grande do Sul weather stations network for daily data.

\begin{tabular}{|c|c|c|}
\hline Validation procedures & Air temperature $\left({ }^{\circ} \mathrm{C}\right)$ & Rainfall (mm) \\
\hline \multirow{4}{*}{ Range test } & $-30<\operatorname{Tmax} ; \operatorname{Tm} ; \operatorname{Tmin}<50$ & \multirow[t]{4}{*}{$0 \leq \mathrm{P} \leq \mathrm{P}_{\mathrm{HIGH}}$} \\
\hline & (Shafer et al., 2000) & \\
\hline & TLOW $_{\text {L Tmax }} ; \mathrm{Tm} ;$ Tmin $<\mathrm{THIGH}_{\text {H }}$ & \\
\hline & (AEMET, 2008) & \\
\hline \multirow{2}{*}{ Step test } & $\operatorname{Tm}-\operatorname{Tm}_{(\mathrm{d}-1)}<25$ & \multirow{2}{*}{ None } \\
\hline & (WMO, 2008) & \\
\hline \multirow{4}{*}{ Internal consistency test } & $\operatorname{Tmax}_{(\mathrm{d})}>\operatorname{Tm}_{(\mathrm{d})}>\operatorname{Tmin}_{(\mathrm{d})}$ & \multirow{4}{*}{ None } \\
\hline & $\operatorname{Tmax}_{(\mathrm{d})}>\operatorname{Tm}_{(\mathrm{d}-1)}$ & \\
\hline & $\operatorname{Tm}_{(\mathrm{d})} \leq \operatorname{Tmax}(\mathrm{d}-1)$ & \\
\hline & (Reek et al., 1992; Feng et al., 2004) & \\
\hline
\end{tabular}

Tm: daily mean temperature $\left({ }^{\circ} \mathrm{C}\right)$; Tmax: daily maximum temperature $\left({ }^{\circ} \mathrm{C}\right)$; Tmin: daily minimum temperature $\left({ }^{\circ} \mathrm{C}\right)$; TLow: minimum temperature value measured in long-term observatory closer or to each station $\left({ }^{\circ} \mathrm{C}\right)$ and $\mathrm{T}_{\text {HIGH: }}$ maximum temperature value measured in long-term observatory closer or to each station $\left({ }^{\circ} \mathrm{C}\right)(\mathrm{Inmet}, 2018)$; P: daily

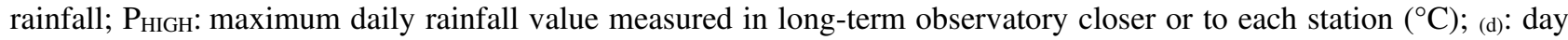
and $(\mathrm{d}-1)$ : day before day.

Tropical Pacific Ocean's surface-temperature anomalies from October-November-December (OND) to March-April-May (MAM) of each year were taken from NOAA (2018).

Typical soil of each site (Figure 1) was defined based on references, describing soil taxonomy, profile features, granulometry and soil density (Table 2 and Table 3). From sand, silt and clay contents data, soil density, and A and B layers of soil depth - limiting soybean root system 
depth $(\mathrm{Z})$ to $1.2 \mathrm{~m}$, maximum water availability $\left(\theta_{\mathrm{Aw}}\right)$ was calculated through a pedotransfer functions (Reichert et al. 2009) (Equations 1, 2 and 3):

$$
\begin{aligned}
& \theta_{\mathrm{fc}}=0.037+0.38(\text { Clay }+ \text { Silt }) \\
& \theta_{\mathrm{pwp}}=0.236+0.045 \text { Clay }-0.21 \text { Sand } \\
& \theta_{\mathrm{AW}}=\left(\theta_{\mathrm{fc}}-\theta_{\mathrm{wp}}\right) \mathrm{Z} \mathrm{SD}
\end{aligned}
$$

where $\theta_{\mathrm{fc}}$ is the soil moisture at field capacity $\left(\mathrm{kg} \mathrm{kg}^{-1}\right) ; \theta_{\mathrm{pwp}}$ is the soil moisture at permanent wilting point $\left(\mathrm{kg} \mathrm{kg}^{-1}\right)$; Clay, Silt and Sand content $\left(\mathrm{kg} \mathrm{kg}^{-1}\right)$; SD is the soil density $\left(\mathrm{kg} \mathrm{m}^{-3}\right)$; and $\theta_{\mathrm{Aw}}$ is the maximum available water $(\mathrm{mm})$.

From a cluster analysis performed by Melo et al. (2004) with the Ward method, using the Euclidean distance and data from 210 municipalities of soybean production in RS, the 11 sites (Figure 1) were divided into three classes according to soybean yield $\left(\mathrm{Mg} \mathrm{ha}^{-1}\right)$, soybean production (tons) and percentage of soybean cultivated area data (ratio between soybean area and total area of the municipality) as: $\mathrm{A}$ - high yield, $\mathrm{B}$ - medium yield and $\mathrm{C}-$ low yield (Table 2). For each production region, soils are described in terms of texture and hydraulic parameters in Table 3.

\begin{tabular}{|c|c|c|c|c|c|c|}
\hline Site & Lat $\left({ }^{\circ}\right)$ & Long $\left(^{\circ}\right)$ & Height $(\mathrm{m})$ & Cluster & Soil Taxonomy & Information sources \\
\hline Ibirubá & -28.61 & -53.11 & 433.0 & A & $\begin{array}{l}\text { Typic Sombrihumult / } \\
\text { Oxisol }\end{array}$ & $\begin{array}{l}\text { Divisão de Pedologia e } \\
\text { Fertilidade do Solo. Ministério da } \\
\text { Agricultura (1962); Pötter (1980) } \\
\text { Divisão de Pedologia e }\end{array}$ \\
\hline Julio de Castilhos & -28.20 & -53.65 & 440.0 & A & Typic Haplohumult & $\begin{array}{l}\text { Fertilidade do Solo. Ministério da } \\
\text { Agricultura (1962); Zalamena } \\
\text { (2008) }\end{array}$ \\
\hline Lagoa Vermelha & -28.41 & -51.58 & 772.0 & A & Rhodic Hapludox & $\begin{array}{l}\text { Divisão de Pedologia e } \\
\text { Fertilidade do Solo. Ministério da } \\
\text { Agricultura (1962) }\end{array}$ \\
\hline Passo Fundo & -28.25 & -52.40 & 639.0 & A & Rhodic Hapludox & $\begin{array}{l}\text { Divisão de Pedologia e } \\
\text { Fertilidade do Solo. Ministério da } \\
\text { Agricultura (1962); Vieira and } \\
\text { Klein (2007) }\end{array}$ \\
\hline Cruz Alta & -28.63 & -53.60 & 429.0 & $\mathrm{~B}$ & Rhodic Hapludox & $\begin{array}{l}\text { Divisão de Pedologia e } \\
\text { Fertilidade do Solo. Ministério da } \\
\text { Agricultura (1962); Secco et al. } \\
\text { (1997); Secco et al. (2004); } \\
\text { Nunes and Cassol (2008); Genro } \\
\text { Junior et al. (2009) }\end{array}$ \\
\hline Iraí & -27.18 & -53.23 & 262.0 & B & Rhodic Lithic Hapludalf. & Cunha et al. (2010) \\
\hline Santa Rosa & -27.85 & -54.47 & 308.0 & $\mathrm{~B}$ & Rhodic Hapludox & Nicoloso et al. (2008) \\
\hline Bagé & -31.33 & -54.10 & 215.0 & $\mathrm{C}$ & Endoaqualf & $\begin{array}{l}\text { Macedo (1984); Giarola et al. } \\
(2002)\end{array}$ \\
\hline Encruzilhada do Sul & -30.53 & -52.52 & 427.7 & $\mathrm{C}$ & Oxic Paleudult & $\begin{array}{l}\text { Giarola et al. (2002); Cunha et al. } \\
(2005)\end{array}$ \\
\hline Santa Maria & -29.67 & -53.80 & 191.0 & $\mathrm{C}$ & Typic Hapludalf & $\begin{array}{l}\text { Giarola et al. (2002); Reinert et } \\
\text { al. (2008) }\end{array}$ \\
\hline São Luiz Gonzaga & -28.42 & -54.96 & 245.0 & $\mathrm{C}$ & Rhodic Hapludox & $\begin{array}{l}\text { Divisão de Pedologia e } \\
\text { Fertilidade do Solo. Ministério da } \\
\text { Agricultura (1962) }\end{array}$ \\
\hline
\end{tabular}

Table 2. Sites, geographical coordinate of weather station, clusters, soil class, and information sources. 
Table 3. Site, fractions of clay, silt and sand, soil density (SD), maximum exploitable depth of soil $(Z)$, water potential in field capacity $\left(\theta_{\mathrm{fc}}\right)$, water potential in permanent wilting point $\left(\theta_{\text {pwp }}\right)$ and maximum water availability $\left(\theta_{\mathrm{Aw}}\right)$.

\begin{tabular}{lcccccccc}
\hline \multicolumn{1}{c}{ Site } & $\begin{array}{c}\text { Clay } \\
\left(\mathrm{kg} \mathrm{kg}^{-1}\right)\end{array}$ & $\begin{array}{c}\text { Silt } \\
\left(\mathrm{kg} \mathrm{kg}^{-1}\right)\end{array}$ & $\begin{array}{c}\text { Sand } \\
\left(\mathrm{kg} \mathrm{kg}^{-1}\right)\end{array}$ & $\begin{array}{c}\mathrm{SD} \\
\left(\mathrm{kg} \mathrm{m}^{-3}\right)\end{array}$ & $\begin{array}{c}\mathrm{Z} \\
(\mathrm{m})\end{array}$ & $\begin{array}{c}\theta \mathrm{fc} \\
\left(\mathrm{kg} \mathrm{kg}^{-1}\right)\end{array}$ & $\begin{array}{c}\theta \mathrm{pwp} \\
\left(\mathrm{kg} \mathrm{kg}^{-1}\right)\end{array}$ & $\begin{array}{c}\theta_{\mathrm{AW}} \\
(\mathrm{mm})\end{array}$ \\
\hline Ibirubá & 0.560 & 0.240 & 0.200 & 1,110 & 1.00 & 0.341 & 0.219 & 134.0 \\
Júlio de Castilhos & 0.330 & 0.200 & 0.470 & 1,480 & 0.80 & 0.238 & 0.152 & 102.0 \\
Lagoa Vermelha & 0.736 & 0.210 & 0.046 & 1,080 & 1.20 & 0.396 & 0.260 & 177.0 \\
Passo Fundo & 0.450 & 0.310 & 0.240 & 1,430 & 1.20 & 0.326 & 0.206 & 206.0 \\
Cruz Alta & 0.477 & 0.173 & 0.350 & 1,240 & 1.00 & 0.284 & 0.184 & 124.0 \\
Iraí & 0.200 & 0.420 & 0.372 & 1,500 & 0.40 & 0.273 & 0.167 & 63.0 \\
Santa Rosa & 0.641 & 0.312 & 0.047 & 1,430 & 1.00 & 0.399 & 0.255 & 206.0 \\
Bagé & 0.120 & 0.420 & 0.510 & 1,370 & 0.40 & 0.242 & 0.134 & 59.0 \\
Encruzilhada do Sul & 0.298 & 0.260 & 0.441 & 1,490 & 0.50 & 0.249 & 0.157 & 69.0 \\
Santa Maria & 0.140 & 0.300 & 0.560 & 1,400 & 0.55 & 0.204 & 0.125 & 61.0 \\
São Luiz Gonzaga & 0.580 & 0.370 & 0.050 & 1,430 & 0.80 & 0.398 & 0.252 & 167.0 \\
\hline
\end{tabular}

\section{Boundary function to soybean yield gap analyses}

To identify the soybean yield gap, a boundary function (Equation 4) was fitted, relating crop yield and total rainfall through soybean crop (van Ittersum et al. 2013). Zanon et al. (2016) fitted a boundary function for RS from experimental yield and seasonal water supply in rainfed and irrigated soybean crops grown during four growing seasons in RS. This boundary function was adopted and considered as a yield attainable (Yw) because the soybean yield limit matched the ten most productive cultivars at each harvest and place (2008/09 to 2016/17) reported by the national trial of soybean cultivars (ECR 2017).

$\mathrm{Yw}=\mathrm{a}+\mathrm{b}[1-\exp (\mathrm{cx})]$

where $\mathrm{x}$ is the seasonal water supply (rainfall, $\mathrm{mm}$ ) and $\mathrm{a}, \mathrm{b}$ and $\mathrm{c}$ are parameters of the equation model.

Regarding the 11 sites, a previous treatment of the soybean yield data had to be done. Given improvements in genetic and fertilizer applications over the 25 years, which on average caused a yearly increase of $52.9 \mathrm{~kg} \mathrm{ha}^{-1}$ in RS (CONAB, 2018), it was necessary to statistically detrend the time-series of crop yield to remove these factors, and isolate the role of weather. So, soybean yield was detrended using linear regression (Goldblum, 2009).

\section{Soybean water balance}

Furthermore, as a complementary analysis to define the role of water on soybean crop, relationships between soybean yield and water deficit were fitted, therefore integrating soil and plant features and weather data considering the El Niño, La Niña or Neutral weather condition. 
Through this methodology, each unit of water deficit was assessed for different production clusters. To account for the water deficit, water balances $(\mathrm{BH})$ were calculated using the concept of Thornthwaite \& Mather (1955). The maximum available water $\left(\theta_{\mathrm{AW}}\right)$ reflected the root system depth simulation (RSD), thus considering the maximum availability of water $\left[\theta_{\mathrm{AWr}}(\%)\right]$ for each soybean development sub period (Table 4).

Table 4. Soybean development sub periods (Fehr and Caviness 1977): mean time per sub period (Days) and relative water content in relation to the maximum $\left(\theta_{\mathrm{AWr}}\right)$ for the soybean crop.

\begin{tabular}{lcc}
\hline \multicolumn{1}{c}{ Soybean sub periods } & Days $^{1}$ & $\theta_{\mathrm{AWr}}(\%)^{1}$ \\
\hline Establishment (S-V1) & 15 & 30 \\
Vegetative (V2-R1) & 40 & 75 \\
Flowering/Grain filling (R1-R5.5) & 35 & 90 \\
Maturation (R6-R8) & 30 & 100 \\
\hline${ }^{1}$ Battisti (2013) & &
\end{tabular}

For each site (Figure 1), three crop water balances were calculated on a daily scale considering the following sowing data: October 15, November 15 and December 15, recommended by MAPA (2018). To represent cultivars from the relative maturity group 5-6 recommended to soybean macro-region 1 (micro regions 101, 102 and 103), a cycle of 120 days was fixed (Alliprandini et al. 2009, MAPA, 2018).

Soybean evapotranspiration (ETc) was calculated by multiplying the reference evapotranspiration (ETo) (Hargreaves and Samani 1985, Eq 5) by the crop coefficient (Kc). The Kc followed the soybean development (Martorano 2007) (Eq.6):

ETo $=0.0023\left(\frac{\mathrm{Qo}}{2.45}\right)\left(\mathrm{T}_{\max }-\mathrm{T}_{\min }\right)^{-0.5}\left(T_{\text {avg }}+17.8\right)$

where $\mathrm{Qo} / 2.45$ is the extraterrestrial solar radiation $\left(\mathrm{mm}\right.$ day $\left.^{-1}\right) ; \mathrm{T}_{\max }$ is the maximum air temperature $\left({ }^{\circ} \mathrm{C}\right) ; \mathrm{T}_{\min }$ is the minimum air temperature $\left({ }^{\circ} \mathrm{C}\right)$; $\mathrm{T}_{\text {avg }}$ is the average air temperature.

$\mathrm{Kc}=-0.0001(\mathrm{DAE})^{\wedge} 2+0.0168(\mathrm{DAE})+0.4269$

where DAE means days after plant emergency.

Mean comparison statistical analyses were performed using the Tukey test at 5\% of error probability.

\section{Results and discussion}

Air temperature data was not analyzed for associations with El Niño, La Niña or neutral events (Table 5, Figure 2). A simple and comparative analysis presents the thermal nuances among 
the sites in order to identify its influence on soybean evapotranspiration and consequently on the water balance results and crop yield.

From October to January while soybean crops are predominantly in vegetative development stages, besides the thermal differences among sites basically due to the relief, the Rio Grande do Sul also presents a temporal distinction increase of air temperature from spring to summer among sites from low to high altitude (Table 5 and Figure 2). Cluster A sites (Ibirubá, Júlio de Castilhos, Lagoa Vermelha and Passo Fundo), the highest altitude and colder soybean crop areas in RS also show less thermal increase. So, these areas seems to be not thermally suitable for soybean, considering the optimum temperature range for soybean growth is between 20 and $30^{\circ} \mathrm{C}$ (Silva et al., 2015). However, there is an apparent inconsistency since these are the most soybean yieldness sites of RS.

This issue was evaluated by Melo et al. (2004) emphasizing that in sites of Cluster A the thermal condition could restrict the development of soybeans by reducing the growing season of the crop. According to them the air temperature seems to have a greater influence on crop cycle than on the final grain yield. Therefore, in these sites the sowing date must be well adjusted in order to take advantage of the weather, using early varieties adapted to the thermal conditions. This was presented by Melo et al. (2004) and Nóia Júnior et al. (2020) who also point out the risk for the occurrence of low temperature and late freeze events increase during the vegetative phase due to a possible anticipation of sowing to September.

In addition, about the ENSO effects on air temperature in Rio Grande do Sul, Puchalsky (2000), Berlato and Althaus (2010) and Cordeiro et al. (2016) describe that there is a greater influence of La Niña, when the lowest average minimum temperature values are recorded. This ENSO disturbance is quite important for higher altitude sites (Cluster A) due to the increased risks of late freeze for the soybean crop. El Niño, on the other hand, increasing cloudness and rainfall (Fontana and Berlato, 1997; Berlato and Fontana, 2003; Custódio et al., 2009) interfering with the long waves balance, reducing losses, therefore, raising the minimum temperature.

Table 5. Minimum $\left(\mathrm{T}_{\mathrm{LOW}},{ }^{\circ} \mathrm{C}\right)$, maximum $\left(\mathrm{T}_{\mathrm{HIGH}},{ }^{\circ} \mathrm{C}\right)$ and daily mean air temperatures $\left(\mathrm{Tm},{ }^{\circ} \mathrm{C}\right)$ values measured in long-term observatory of each site.

\begin{tabular}{lcccc}
\hline \multicolumn{1}{c}{ Site } & Cluster & $\mathrm{T}_{\text {LOW }}\left({ }^{\circ} \mathrm{C}\right)$ & $\mathrm{T}_{\mathrm{HIGH}}\left({ }^{\circ} \mathrm{C}\right)$ & $\mathrm{Tm}\left({ }^{\circ} \mathrm{C}\right)$ \\
\hline Ibirubá & $\mathrm{A}$ & -4.0 & 40.6 & 18.7 \\
Júlio de Castilhos & $\mathrm{A}$ & -5.8 & 38.4 & 18.5 \\
Lagoa Vermelha & $\mathrm{A}$ & -5.3 & 34.2 & 17.3 \\
Passo Fundo & $\mathrm{A}$ & -3.5 & 36.3 & 18.0 \\
Cruz Alta & $\mathrm{B}$ & -3.0 & 37.5 & 18.8 \\
Irai & $\mathrm{B}$ & -5.3 & 39.2 & 20.4 \\
Santa Rosa & $\mathrm{B}$ & -4.6 & 40.1 & 20.8 \\
Bagé & $\mathrm{C}$ & -3.9 & 39.9 & 17.7
\end{tabular}




\begin{tabular}{ccccc} 
Encruzilhada Do Sul & C & -4.0 & 40.6 & 17.3 \\
Santa Maria & C & -2.9 & 40.2 & 19.4 \\
São Luiz Gonzaga & C & -1.8 & 39.9 & 20.9 \\
\hline Data recording times: Santa Rosa (1922-1949); Julio de Catilhos (1915-1949), others sites (1981-2010).
\end{tabular}

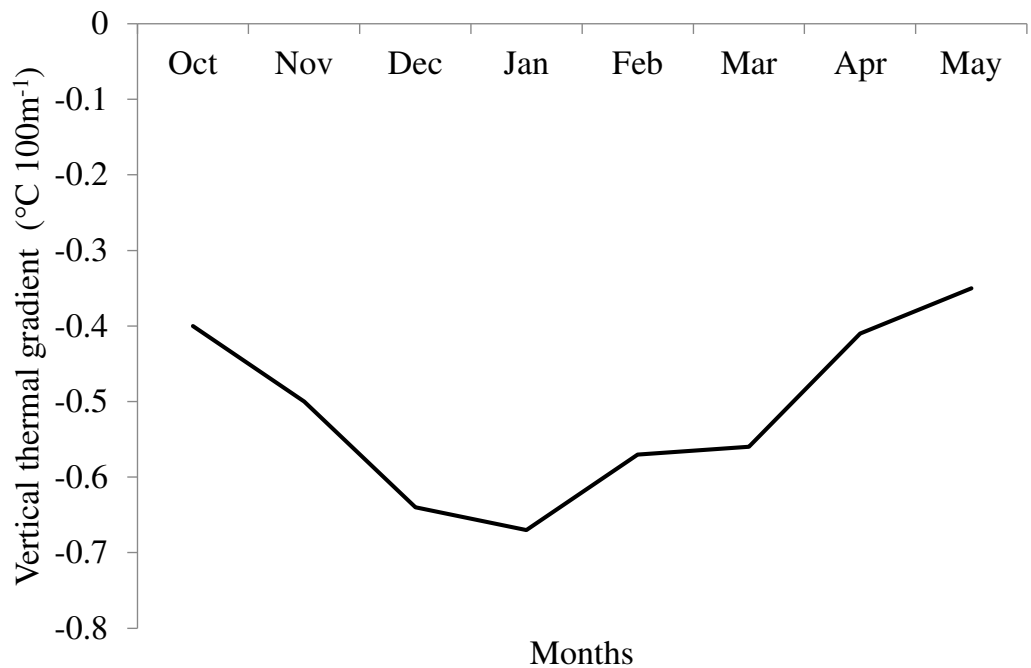

Figure 2. Vertical thermal gradient $\left({ }^{\circ} \mathrm{C} 100 \mathrm{~m}^{-1}\right)$ from October to May among all weather stations.

In the northern region of RS, where most of the soybean production area of the state is, such as Cluster A, there are predominantly clayey soils, with deep horizons A and B with at least $0.8 \mathrm{~m}$, resulting in maximum water availability ranging from 102 to $206 \mathrm{~mm}$ (Table 3). In sites of Clusters B, the soils are clayey and deeper too, excepted Iraí (Table 3).

Sites of clusters A and B differ mainly by altitude and air temperature (Table 2). As previous set (Table 5, Figure 2) sites in A (higher altitude) have lower temperature than sites in B, an important issue regarding to soybean evapotranspiration, which is minimized, reducing occurrences of water deficiency and thus favoring production (Pilau et al., 2018).

Sites of cluster $\mathrm{C}$ are in less clayey and also shallower soils areas, with lower water holding capacity (Table 3). In addition, they represent the areas of low altitude and higher temperatures (THIGH) of Rio Grande do Sul (Figure 2). In these sites, as an sample of how ENSO can influence, based on monthly mean temperature along the soybean crop season, the literature shows that in the Central region of the State (Santa Maria, see Fig. 1) the pan class A evaporative rate (ECA) and air humidity (RH) are strongly dependent on ENSO (Streck et al., 2008). These authors found lower ECA values and higher RH values during El Niño years, and higher ECA values and lower RH values during La Niña years.

Although the results can contradict the thermal aspects described by Puchalsky (2000) about ENSO influence, these results are also connected to cloudiness and number of rainy days, both with 
positive deviations in El Niño years in relation to normality, which usually results in yield gain under El Niño and yield losses under La Niña (Berlato and Fontana, 1999).

Also, Gelcer et al. (2013) through the Agricultural Reference Index for Drought (ARID) and Cordeiro et al (2018) using the relative evapotranspiration (actual/potential evapotranspiration rate) described the influence of ENSO for Rio Grande do Sul, showing El Niño events determining lower water stress, and the opposite for La Niña events. They also showed that in the Southern part of the state (represented by Bagé and Encruzilhada do Sul in Figure 1), there was a higher frequency of water stress events, mainly from November to January during La Niña. These results corroborates the lack of water availability in the Southern part of the state for rainfed spring-summer crops, which can be used to support crop management decisions based on forecasts of El Niño or La Niña.

In summary, our results together with the literature shows that ENSO phenomenon can also have influence on the thermal atmosphere condition, particularly influencing the water consumption of rainfed spring-summer crops in the State (Table 5; Figure 2). Still, considering that the average rainfall during the spring and summer in the State of Rio Grande do Sul is generally insufficient to meet the soybean water requirements (Ávila et al. 1996) the evapotranspiration rates reduction mainly observed in EI Niño seasons (Gelcer et al., 2013; Cordeiro et al., 2018) can favor the crop.

Regarding rainfall in RS, influences of the ENSO phenomenon mainly coincide with the soybean season in the state (Table 6). The first time of interference of the warm phase, El Niño, is at the end of the year of the phenomenon, especially during OND with a peal at the end of autumn of the following year (+) (MAM). For La Niña years, there are two events coinciding with those of the warm phase (Matzenauer et al. 2017). The first one, from October to November (OND) coinciding with sowing and vegetative development of soybeans, which may affect sowing and delaying the establishment of the crop. The second one is related to the increase in the frequency and intensity of rainfall from April to June (MAM), which could favor or harm the yield and harvest progress according to sowing date and soybean cultivar cycle.

Regarding the 25 seasons considered in our study (Table 6), eight were classified as Neutral, nine as El Niño and eight as La Ninã phases. For El Niño anomaly, two years/harvests stood out: $1997 / 1998\left(1.9^{\circ} \mathrm{C}\right)$ and $2015 / 16\left(2.1^{\circ} \mathrm{C}\right)$. The cumulative rainfall exceeded 1,000 $\mathrm{mm}$ in the crop cycle, which was not different $(p>0.05)$ among Clusters. Under influence of a weak El Niño, 1994/95 season was the only one to show statistical difference of cumulative rainfall among Clusters, while retaining similarity between Clusters A and B with higher accumulated rainfall, but not differing $\mathrm{B}$ from $\mathrm{C}$. 
For La Niña, only two cases were different $(p<0.05)$ between Clusters. In 2008/09 (weak La Niña), Cluster C had lower rainfall than Cluster A. In 2010/11 (moderate La Niña) again the sites of Cluster C stood out negatively, however differing from Cluster B instead of A (Table 6). No season had statistical difference of rainfall among Clusters A, B and C (Table 5) under Neutral conditions.

Results (Table 6) agree with Matzenauer et al. (2017) data, identifying higher rainfall volumes in the north and northwest RS, where Clusters A and B are set, especially in the spring months. Similarly, the center-southern of RS (Cluster C) under the influence of La Niña had lower rainfall for the same period of the year as well (Grimm et al. 1998; Grimm et al. 2000).

Recent data show that different types of ENSO influence the atmospheric fields differently. Southern Brazil has positive rainfall anomalies during East El Niño (EEN) what do not happen with Central El Niño (CEN) (Tedeschi et al. 2015). Besides, the ENSO-related changes in the frequency of extreme rainfall events are generally coherent with changes in total monthly rainfall quantities. However, significant changes in extremes are much more extensive than the corresponding changes in monthly rainfall because the highest sensitivity to ENSO seems to be in the extreme range of daily rainfall, specially affecting basins with predominance of agricultural areas (Chagas and Chaffe 2018).

About La Niña phase, Grimm et al. (2000) reinforces the previously reported, detaching the dryness weather prevailing in November over south Brazil, triggering water deficit in the sowing period of soybean, while in December and January the rainfall is near normal. The negative anomalies return in February (Grimm and Tedeschi 2008), this time matching with flowering/formation pod and soybean grains stages.

Table 6. Tropical Pacific Ocean surface temperature anomaly from October-November-December (OND) to March-April-May (MAM), average surface temperature anomaly (Tavg), weather condition and average rainfall during soybean crop for each Cluster (A, B and C).

\begin{tabular}{crrrrrrcccccc}
\hline \multicolumn{1}{c}{ Sea Temperature Anomaly $\left({ }^{\circ} \mathrm{C}\right)$} & \multicolumn{3}{c}{$\begin{array}{c}\text { Avg. sea } \\
\text { temp. season } \\
\text { Harvest }\end{array}$} & OND & NDJ & DJF & JFM & FMA & MAM $\begin{array}{c}\text { Weather } \\
\text { Condition } \\
\left(\Delta \text { Tavg; }{ }^{\circ} \mathrm{C}\right)\end{array}$ & Cluster A & Cluster B & Cluster C \\
\hline $1991 / 92$ & 1.2 & 1.6 & 1.7 & 1.6 & 1.5 & 1.3 & 1.5 & El Niño & $587.35 \mathrm{a}$ & $663.78 \mathrm{a}$ & $664.88 \mathrm{a}$ \\
$1992 / 93$ & -0.3 & 0.1 & 0.1 & 0.3 & 0.5 & 0.7 & 0.2 & Neutral & $680.55 \mathrm{a}$ & $589.69 \mathrm{a}$ & $629.37 \mathrm{a}$ \\
$1993 / 94$ & 0.0 & 0.1 & 0.1 & 0.1 & 0.2 & 0.3 & 0.1 & Neutral & $658.92 \mathrm{a}$ & $722.64 \mathrm{a}$ & $752.25 \mathrm{a}$ \\
$1994 / 95$ & 1.0 & 1.1 & 1.0 & 0.7 & 0.5 & 0.3 & 0.8 & El Niño & $833.42 \mathrm{a}$ & $713.99 \mathrm{ab}$ & $583.37 \mathrm{~b}$ \\
$1995 / 96$ & -1.0 & -1.0 & -0.9 & -0.8 & -0.6 & -0.4 & -0.8 & La Niña & $650.73 \mathrm{a}$ & $585.33 \mathrm{a}$ & $644.99 \mathrm{a}$ \\
$1996 / 97$ & -0.4 & -0.5 & -0.5 & -0.4 & -0.1 & 0.3 & -0.3 & Neutral & $581.91 \mathrm{a}$ & $581.46 \mathrm{a}$ & $516.10 \mathrm{a}$ \\
$1997 / 98$ & 2.4 & 2.4 & 2.2 & 1.9 & 1.4 & 1.0 & 1.9 & El Niño & $1024.15 \mathrm{a}$ & $1083.12 \mathrm{a}$ & $1161.51 \mathrm{a}$ \\
$1998 / 99$ & -1.5 & -1.6 & -1.5 & -1.3 & -1.1 & -1.0 & -1.3 & La Niña & $538.69 \mathrm{a}$ & $454.99 \mathrm{a}$ & $461.59 \mathrm{a}$ \\
$1999 / 00$ & -1.5 & -1.7 & -1.7 & -1.4 & -1.1 & -0.8 & -1.4 & La Niña & $639.15 \mathrm{a}$ & $521.01 \mathrm{a}$ & $499.52 \mathrm{a}$
\end{tabular}




\begin{tabular}{rrrrrrrrrrrr}
$2000 / 01$ & -0.7 & -0.7 & -0.7 & -0.5 & -0.4 & -0.3 & -0.6 & La Niña & $676.08 \mathrm{a}$ & $674.58 \mathrm{a}$ & $690.68 \mathrm{a}$ \\
$2001 / 02$ & -0.3 & -0.3 & -0.1 & 0.0 & 0.1 & 0.2 & -0.1 & Neutral & $572.11 \mathrm{a}$ & $445.11 \mathrm{a}$ & $557.77 \mathrm{a}$ \\
$2002 / 03$ & 1.3 & 1.1 & 0.9 & 0.6 & 0.4 & 0.0 & 0.7 & El Niño & $915.77 \mathrm{a}$ & $988.99 \mathrm{a}$ & $961.49 \mathrm{a}$ \\
$2003 / 04$ & 0.4 & 0.4 & 0.4 & 0.3 & 0.2 & 0.2 & 0.3 & Neutral & $713.33 \mathrm{a}$ & $676.21 \mathrm{a}$ & $617.63 \mathrm{a}$ \\
$2004 / 05$ & 0.7 & 0.7 & 0.6 & 0.6 & 0.4 & 0.4 & 0.6 & El Niño & $457.39 \mathrm{a}$ & $448.32 \mathrm{a}$ & $420.13 \mathrm{a}$ \\
$2005 / 06$ & -0.6 & -0.8 & -0.8 & 0.7 & -0.5 & -0.3 & -0.4 & Neutral & $557.98 \mathrm{a}$ & $506.28 \mathrm{a}$ & $426.94 \mathrm{a}$ \\
$2006 / 07$ & 0.9 & 0.9 & 0.7 & 0.3 & 0.0 & -0.2 & 0.4 & El Niño & $724.41 \mathrm{a}$ & $628.42 \mathrm{a}$ & $702.76 \mathrm{a}$ \\
$2007 / 08$ & -1.5 & -1.6 & -1.6 & -1.4 & -1.2 & -0.9 & -1.4 & La Niña & $638.68 \mathrm{a}$ & $526.69 \mathrm{a}$ & $453.82 \mathrm{a}$ \\
$2008 / 09$ & -0.6 & -0.7 & -0.8 & -0.7 & -0.5 & -0.2 & -0.6 & La Niña & $566.51 \mathrm{a}$ & $530.56 \mathrm{ab}$ & $491.47 \mathrm{~b}$ \\
$2009 / 10$ & 1.3 & 1.6 & 1.5 & 1.3 & 0.9 & 0.4 & 1.2 & El Niño & $1041.19 \mathrm{a}$ & $809.80 \mathrm{a}$ & $1093.33 \mathrm{a}$ \\
$2010 / 11$ & -1.7 & -1.6 & -1.4 & -1.1 & -0.8 & -0.6 & -1.2 & La Niña & $618.77 \mathrm{ab}$ & $790.94 \mathrm{a}$ & $484.73 \mathrm{~b}$ \\
$2011 / 12$ & -1.1 & -1.0 & -0.8 & -0.6 & -0.5 & -0.4 & -0.7 & La Niña & $463.04 \mathrm{a}$ & $366.10 \mathrm{a}$ & $355.87 \mathrm{a}$ \\
$2012 / 13$ & 0.0 & -0.4 & -0.4 & -0.3 & -0.2 & -0.2 & -0.3 & Neutral & $786.15 \mathrm{a}$ & $866.18 \mathrm{a}$ & $667.39 \mathrm{a}$ \\
$2013 / 14$ & -0.2 & -0.3 & -0.4 & -0.4 & -0.2 & 0.1 & -0.2 & Neutral & $819.71 \mathrm{a}$ & $654.17 \mathrm{a}$ & $722.59 \mathrm{a}$ \\
$2014 / 15$ & 0.6 & 0.7 & 0.6 & 0.6 & 0.6 & 0.8 & 0.7 & El Niño & $959.22 \mathrm{a}$ & $897.52 \mathrm{a}$ & $834.05 \mathrm{a}$ \\
$2015 / 16$ & 2.5 & 2.6 & 2.5 & 2.2 & 1.7 & 1.0 & 2.1 & El Niño & $1011.58 \mathrm{a}$ & $1194.84 \mathrm{a}$ & $968.02 \mathrm{a}$ \\
\hline
\end{tabular}

Values in rows followed by the same letter do not differ significantly at 5\% probability by Tukey test.

According to average rainfall data of each Cluster (Table 7), regarding to neutrality conditions or ENSO influence, rainfall in Cluster A was statistically different according to the ENSO phase. For La Niña, it was $8 \%$ lower than in Neutral conditions despite the statistical equality between data, and $31 \%$ lower than the average for El Niño.

Results for Cluster B presented the same statistical description as Cluster A (Table 7), with average rainfall along the soybean cycle very similar for each weather condition. For Cluster C statistical analyses used rainfall data for El Niño upper and distinct seasons from the other two weather conditions.

It is important to note that although the average rainfall is lower during La Nina (Table 7), there were several El Niño and neutral seasons in which rainfall was lower than those thresholds. Regarding cluster A 599,0mm (La Niña average, see Table 7), precipitation did not exceed this value in three neutral season (1996/97, 2001/02 and 2005/06) and two times under El Niño (1991/92 and 2004/05) phase (Table 6). In cluster B, two neutral seasons (2001/02 and 2005/06) and one El Niño season (2004/05) did not reach the $556.3 \mathrm{~mm}$ La Niña average (Table 7). In cluster C only one neutral (2005/06) and one El Niño (2004/05) season did not match the average of $510.3 \mathrm{~mm}$ La Niña average (Table 7). This more pronounce influence of ENSO warm phase on sites as Santa Maria and Bagé, Cluster C, was also presented by Nóia Junior et al. (2020).

The spatial and temporal variability of precipitation in RS emphasize a differentiated atmospheric circulation dynamics in the north compared to the south. In the north of RS, in addition to the influence of frontal systems, this region is subject to the performance of tropical systems in summer, which are more intense. This intensification associated with orography (mainly in the northeast of the state) explains the greater rainfall in the north of the state (Britto et al., 2008). 
These results (Tables 6 and 7) also corroborate with the spatial distribution of the effects of ENSO on weather conditions reported by Fontana \& Berlato (1997) for RS. In the study the authors highlighting reductions of 80 to $120 \mathrm{~mm}$ of rainfall in most of the state under La Niña phase, pointing out the western portion of RS as the most affected by the phenomenon.

The results also showed that the largest rainfall accumulated in El Niño years are in the North and Northwest regions (Cruz Alta, Ibirubá, Lagoa Vermelha, Julio de Castilhos and Passo Fundo) the geographical position of Cluster A. Lower rainfall data exist in areas of the Northeastern and Upper Plateau, part of the Central Depression and the Campaign and to the extreme west in the Low Valley of Uruguay. Even smaller volumes cover an Eastern part of the state on the North Coast passing through the Central Depression region (Santa Maria - Cluster C), the Southeastern region (Encruzilhada do Sul - Cluster C), moving towards the Campaign region (Bagé - Cluster C) (Matzenauer et al. 2017).

From mean rainfall data of each cluster (Table 7) it is defined that under neutral condition total rainfall (within soybean production period) is higher in Cluster A than in B and C (statistically not defined), which under influence of El Niño have much more close values. Therefore, as already emphasized B and C sites seem to be more benefited by the phenomenon (Figure 3). Nóia Junior et al (2020) mention that for Santa Maria and Bagé (cluster C) the number of dry periods (seven consecutive days with no rainfall) events was greatly affected by ENSO in most of the tested soybean sowing dates, increasing during La Niña events in both phenological phases and decreased during El Niño years.

Even so, water deficit is lower on Cluster A sites, basically due to soil (water retention) (Table 3) and air temperature (more crop suitable) (Figure 2). Under La Niña events, Clusters B and $\mathrm{C}$ sites again appear to be more vulnerable to changes, in those cases with negative signals because the total rainfall in the soybean production time remains below those from Cluster A (Table 7).

Our results agreed with Grimm et al. (2000) who point out Southern Brazil, specially Rio Grande do Sul, as the region with the strongest signal in the El Niño event in Southern South America (Table 6; Table 7). Based on average rainfall values it can be observed that Rio Grande do Sul has higher rainfall at El Niño events and less rainfall at La Niña phase (Table 7) for all clusters. Despite the differences it is essential to highlight the statistical equality between data of the neutrality condition and La Niña.

Although average data (Table 7) point to El Niño's benefits for local soybean production (Figure 4) since rainfall under neutrality indicated climatic risk (Ávila et al. 1996), the observed variability of rainfall (Table 6) indicate that ENSO's impacts on crop yields form a complex pattern, and that the impacts vary among different geographical locations, different crop sowing data and cycles, different ENSO phases, different seasons and different technology adopted 
by crop-producing areas (Pscheidt \& Grimm 2009; Iizumi et al. 2014; Nóia Junior \& Sentelhas, 2019).

Table 7. Mean values of rainfall, water deficit and soybean yield according to ENSO phases and Clusters A, B and C.

\begin{tabular}{lccc}
\hline ENSO Phase & Rainfall $(\mathrm{mm})$ & Water deficit $(\mathrm{mm})$ & Yield $\left(\mathrm{Mg} \mathrm{ha}^{-1}\right)$ \\
\hline Neutral & $671.3 \mathrm{ab}$ & $2.83 \mathrm{a}$ \\
La Niña & $599.0 \mathrm{~b}$ & $117.8 \mathrm{a}$ & $2.72 \mathrm{a}$ \\
El Niño & $839.4 \mathrm{a}$ & $86.4 \mathrm{a}$ & $3.03 \mathrm{a}$ \\
\hline \multicolumn{4}{c}{ Cluster B } \\
\hline Neutral & $630.2 \mathrm{ab}$ & $2.31^{\mathrm{a}}$ \\
La Niña & $556.3 \mathrm{~b}$ & $244.0 \mathrm{a}$ & $2.19^{\mathrm{a}}$ \\
El Niño & $825.4 \mathrm{a}$ & $171.2 \mathrm{~b}$ & $2.53^{\mathrm{a}}$ \\
\hline \multicolumn{5}{c}{ Cluster C } \\
\hline Neutro & $611.3 \mathrm{~b}$ & $241.5 \mathrm{ab}$ \\
La Niña & $510.3 \mathrm{~b}$ & $289.4 \mathrm{a}$ & $1.87^{\mathrm{a}}$ \\
El Niño & $821.1 \mathrm{a}$ & $192.2 \mathrm{~b}$ & $1.69^{\mathrm{a}}$ \\
\hline Values in columns followed by the same letter do not differ significantly at 5\% probability by Tukey test.
\end{tabular}

Average precipitation data reveal the difference between the hot and cold phases of ENSO (Table 7). However, the variability observed among years under the same weather condition characterizes the importance of the intensity of the phenomenon (Table 6). The relationship between cumulative rainfall and $\Delta$ Tavg for each Cluster shows distinct influence of the phenomenon on local weather due to its intensity (Figure 3). Linear coefficients indicate mean rainfall for Neutral weather of $702 \mathrm{~mm}$ for Cluster A, $676 \mathrm{~mm}$ for Cluster B and $648 \mathrm{~mm}$ for Cluster $\mathrm{C}$, all below $800 \mathrm{~mm}$ required to maximize soybean yield based on the full attendance of water requirement (Figure 4).

The weather condition already unfavorable to soybeans in neutral years becomes even worse under the influence of La Niña (Figure 3). Angular coefficients of the linear adjusted graphic (Figure 3) distinguished them among Clusters. Cluster A sites confirm to be the least influenced by ENSO, due to higher stability of water availability for the soybean crop. On the other hand, Cluster $\mathrm{C}$ sites $\left( \pm 158 \mathrm{~mm}^{\circ} \mathrm{C}^{-1}\right)$ are the most disturbed, characterizing sites with higher climate risk of yield loss (MAPA 2018). In cluster sites A the interaction between soils with greater water storage capacity (Table 3) and colder air temperature (Figure 2) results in lower values of soybean water deficiency (Table 7). So, in most soybean crop years, even with total rainfall close to Clusters B and C sites especially at neutral condition (Table 7), Cluster A seems to be more suitable and least risk places for the production of soybeans in RS (Figure 3). 
Besides soil type (due to maximum water availability - $\theta_{\mathrm{Aw}}$ ) (Table 3), an important issue related to the increase/decrease rainfall relative to the $\Delta$ Tavg (Figure 3 ) is the water drainage capacity (not shown). This last issue is extremely important in Cluster $\mathrm{C}$ areas, such as Bagé, Encruzilhada do Sul and Santa Maria, in which soils show limited drainage with superficial water table. As these sites are highly influenced by the positive phase of ENOS (El Niño) (Figure 3), often with intense rainfall above normal (Table 5), these areas are more susceptible to damages not only due to water deficiency, but also caused by flooding (Zanon et al., 2015).

Cluster A

Cluster B
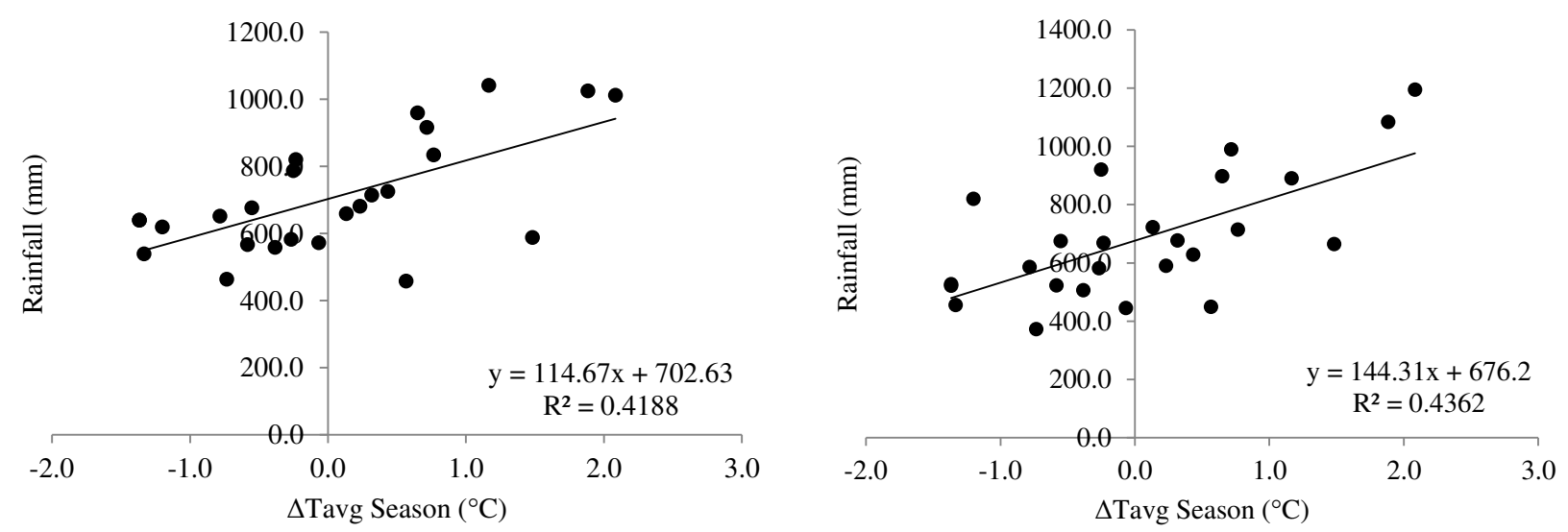

\section{Cluster C}

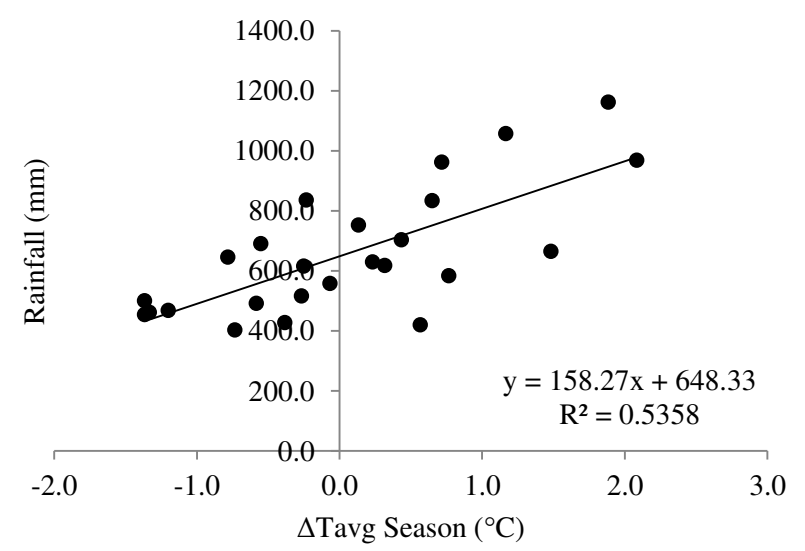

Figure 3. Relationship between mean cumulative rainfall $(\mathrm{mm})$ and mean temperature deviation of the Central Equatorial Pacific Ocean Surface $\left({ }^{\circ} \mathrm{C}\right)$ (OND to MAM seasons).

A boundary function relating soybean yield and rainfall (Figure 4) displays the limit of 800 $\mathrm{mm}$ for yield increments. So, taking this threshold, according to linear adjustments (Figure 3) in all sites, this condition is only achieved under the influence of El Niño. So, the $800 \mathrm{~mm}$ threshold is only achieved with a $\Delta$ Tavg of at least $+0.85^{\circ} \mathrm{C}$ in comparison to Clusters $\mathrm{A}$ and $\mathrm{B}$ and of $+0.95{ }^{\circ} \mathrm{C}$ for Cluster C. 
Similarly, Zanon et al. (2016) noted no increasing yield beyond 800-mm of rainfall, $6.0 \mathrm{Mg}$ $\mathrm{ha}^{-1}$ being the ceiling point of Ya. This was consolidated by experimental data of soybean field trials (Figure 4), where soybean yield ranged from 0.3 to $6.0 \mathrm{Mg} \mathrm{ha}^{-1}$. For the western U.S. Corn Belt, Grassini et al. (2015) found no further yield increase beyond $650 \mathrm{~mm}$, as this should be sufficient to satisfy crop water requirements for the highest yields at such climate conditions.

The boundary function suggested by Zanon et al. (2016) had a slope (attainable water productivity) of $9.1 \mathrm{~kg}$ grain $\mathrm{mm}^{-1} \mathrm{ha}^{-1}$, higher than the $6.1 \mathrm{~kg}$ grain $\mathrm{mm}^{-1} \mathrm{ha}^{-1}$ average of municipal soybean yield data (Figure 4). A practically equal difference was observed when analyzing the 9.9 $\mathrm{kg} \mathrm{mm}^{-1} \mathrm{ha}^{-1}$ determined by Grassini et al. (2015). Regarding the x-intercept of $183 \mathrm{~mm}$ also described by Zanon et al. (2016), the boundary layer fitted indicating higher water consumption as seasonal soil evaporation of $255 \mathrm{~mm}$ (about $40 \%$ higher). Compared to $\mathrm{x}$-intercept $=73 \mathrm{~mm}$ for the western U.S. Corn Belt (Grassini et al. 2015), even Zanon et al. (2016) exposes a much higher average seasonal amount of soil evaporation for RS.

Therefore, according to seasonal water supply (800-mm threshold) and maximum attainable grain yield ( 6.0 $\left.\mathrm{Mg} \mathrm{ha}^{-1}\right)$, in macro analysis - municipal scale, there would be a soybean yield gap of $1.88 \mathrm{Mg} \mathrm{ha}^{-1}$ in RS, which exposes differences in management and technologies employed in the production of soybean.

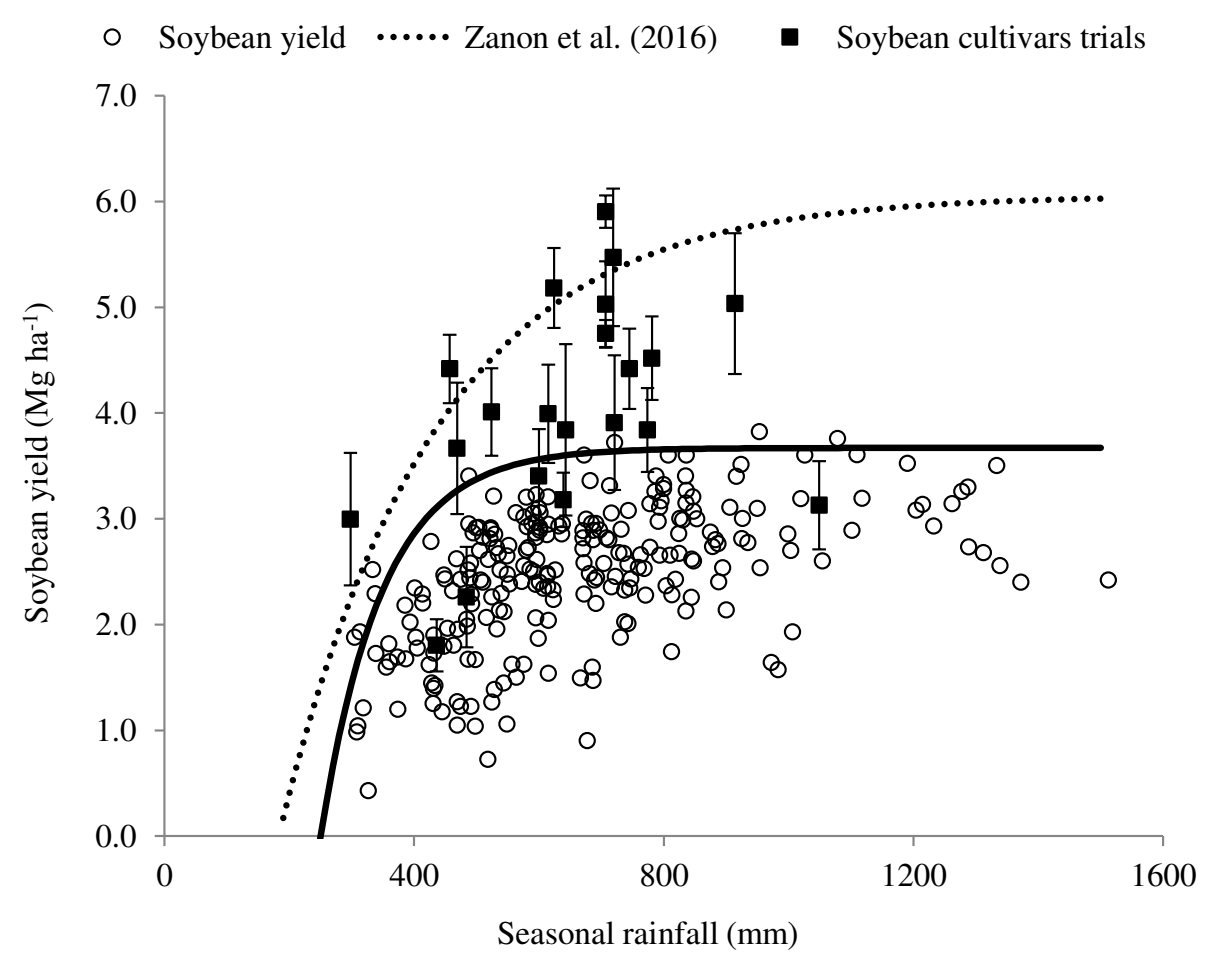

Figure 4. Soybean yield plotted against seasonal rainfall, boundary layer for attainable yield (Yw) and soybean yield data from cultivars trials. 
Based on the $800 \mathrm{~mm}$ found out as the threshold (Figure 4), it can be inferred that $80.8 \%$ of site-years cases were water limited (for Neutral 88\% and La Niña 94\%) (Table 6 and Figure 4). The results for El Niño influence (61\%) (Table 6) highlights the point that, even in the face of a largescale phenomenon, generally considered positive for soybean production because it brings punctual increases in rainfall, weather can often imposes restrictions for soybean crop (Table 6; Figure 4) as described by Cirino et al. (2015). Additionally, Calviño and Sadras (1999) already indicated that water availability was limiting on farm yield in 54\% of the years in the Argentinean Pampas and also for RS soybean areas, suggesting the profitability of this cropping system can be substantially enhanced with practices and cultivars aimed at increasing available water and water-use efficiency.

As established by Purcell and Specht (2004) and Nóia Junior and Sentelhas (2019) the availability of water to the plant depends not only on the amount and temporal distribution of rainfall and its disturbances caused by phenomena such as ENSO (Figure 3), but indisputably on soil type - water storage capacity (Table 3), as well as crop growth stage and variation in available energy - solar radiation and temperature. All of these show natural variability even in small tracts of land. Considering these variables, water balance can make water deficiency available as an alternative index to be correlated with soybean grain yield (Figure 5).

Through individual analysis of each site, the combined effect of rainfall + soil on soybean yield can be seen in Figure 5, in which linear adjustments between soybean yield and water deficit can support water valuing from the angular coefficient (a) and project the attainable soybean yield (municipality) performed from the linear one (b). Although in Cluster A water deficit was lower than $200 \mathrm{~mm}$ (Figure 5), sites less influenced by ENSO phenomena (Figure 3) and with high soil water retention (Table 3) (Julio de Castilhos, Lagoa Vermelha, Passo Fundo and Ibirubá) presented the highest cost for water $\left(-15.2 \mathrm{~kg} \mathrm{~mm}^{-1} \mathrm{ha}^{-1}\right)$. These sites were included with those of higher yields and production in RS (Melo et al. 2004) and were in the preferential zone for soybean crop, when analyzed in relation to loss of yield potential due to water deficits (Cunha et al. 2001).

It is clearly the combination of weather predisposed by ENSO phenomenon (Figure 3), coupled with soils less suitable for soybean cultivation (Table 3), that make the sites less productive and therefore less costly in relation to water deficiency (Figure 5), leading Cluster B to an average loss of $-7.4 \mathrm{~kg} \mathrm{~mm}^{-1} \mathrm{ha}^{-1}$ and Cluster $\mathrm{C}-3.7 \mathrm{~kg} \mathrm{~mm}^{-1} \mathrm{ha}^{-1}$.

From the identification of the harvests corresponding to Neutral, La Niña or El Niño weather conditions (Figure 5), it is El Niño that normally leads to significant yield gains, especially in extreme events by increasing rainfall (Figure 3) and thus reaching the limit to maximize yield (Figure 4). The reason for the positive yield response of the rainfed soybean is that, there is an increase in rainfall compared to Neutral, which is already limiting to meet the crop water needs, and La Nina years, in which there is an even worse condition for soybean in terms of water availability. 
Results such as those obtained by us help to understand the relationship between interanual climate and soybean, although as sad to Letson and McCullought (2001) they were not able to attribute the relationship to ENSO or to say that it is economically important.

Cluster A
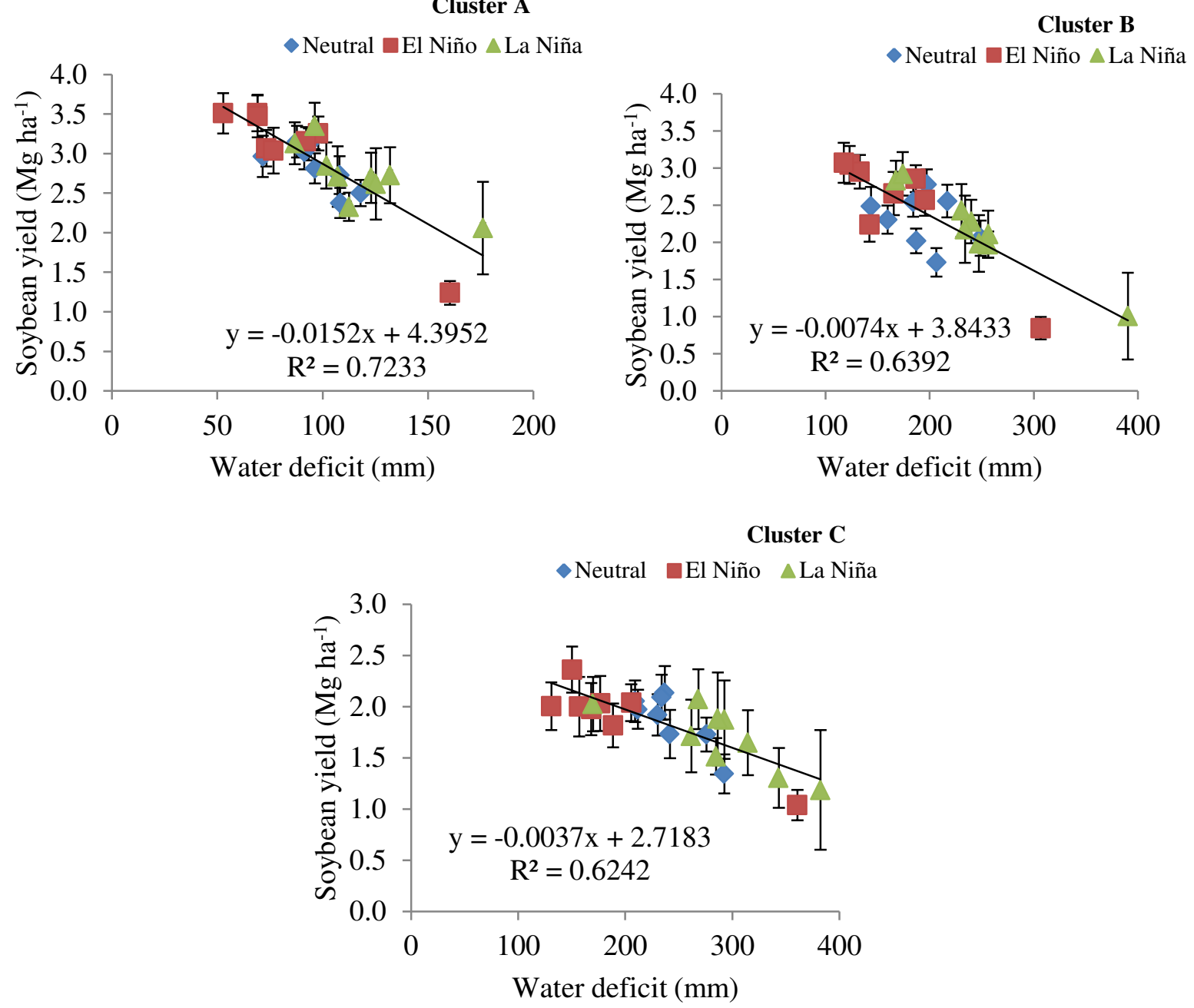

Figure 5. Relationship between soybean yield and water deficit (mm) for different ENSO phases (Neutral, El Niño and La Niña) for Clusters A, B and C.

\section{Conclusions}

In this paper we explore the role of weather, ENSO and soils on soybean yield in Southern Brazil. Eleven assessed sites grouped in three clusters (A, B and C) presented soil distinction, mainly due to water retention capacity, generally higher in Cluster A. Daily rainfall data from 1991 to 2017, relative to months from October to May, help us to understand the action of the ENSO phenomenon in Rio Grande do Sul. Comparing sites in neutral years, Clusters B and C have less rainfall (on average $-49 \mathrm{~mm}$ and $-75 \mathrm{~mm}$ respectively) than Cluster A. In addition, with similar rainfall among cluster under El Niño and distinct (negative deviations) under the opposite ENSO 
phase, indicate sites of Clusters B and C as more severely disturbed by the ENSO phenomenon. Relationship between soybean yield and rainfall for each soybean production year (1991 to 2017) and sites pointed the $800-\mathrm{mm}$ rainfall as needed to maximize soybean yield. Differences between soybean attainable ( $\mathrm{Yw}$ ) and average yields of sites quantitatively establish the productive gap of the soybean in RS, and highlighting the variability among producing regions in terms of investment, technology and cropping systems. An inverse relationship between soybean water deficiency and

yield reinforces the lower quality of the soil for soybean production and the negative effects even more pronounced in years of Neutral and La Niña phenomenon and its rainfall well below what is required to assure high yield levels. We identified the Cluster A as benefited by the thermal regime positively affecting soybean growth, development and water use. Decision-making on public policies and investments on the soybean industry can be supported from our results, either to reduce temporal production variability in the region and risks inherent to local weather.

\section{Declarations}

Funding: not applicable

Conflicts of interest/Competing interests: The authors declare that they have no conflict of interest.

Availability of data and material: The weather data that support the findings of this study are openly available in INMET and NOAA websites. Soil data are available in the literature cited. All material is described in the manuscript. More information can be shared upon requested.

Code availability: not applicable

Author's contributions: FGP - conceptualization, data collection and organization, data analysis, writing and editing; FRM - data analysis, writing and editing; DAVG - data analysis and editing; GAD - data analysis and editing.

\section{References}

1. AEMET (2008) Resumen de extremos climatológicos en España. <http://www.aemet.es/documentos/es/divulgacion/resumen_efemerides/Resumen_extremos.pdf. Accessed 02 March 2019 
2. Alexandersson H (1986) A homogeneity test applied to precipitation data. Journal of Climatology 6:661-675.

3. Alliprandini LF, Abatti C, Bertagnolli PF, Cavassim JE, Gabe HL, Kurek A, Matsumoto MN, Oliveira MAR de, Pitol C, Prado C, Steckling C (2009) Understanding soybean maturity groups in Brazil: environment, cultivar classification, and stability. Crop Science 49:801-808. doi: 10.2135/cropsci2008.07.0390

4. Arsego, DA, Ferraz, SET, Streck, NA, Cardoso, A de O, Zanon, AJ (2018) Estudo do impacto de diferentes índices associados ao El Niño Oscilação Sul na produtividade de soja no Rio Grande do Sul. Ciência e Natura 40:82-87. DOI:10.5902/2179460X30684

5. Ávila A M H de, Berlato M A, Silva J B da, Fontana D C (1996). Probabilidade de ocorrência de precipitação pluvial mensal igual ou maior que a evapotranspiração potencial para a estação de crescimento das culturas de primavera-verão no estado do Rio Grande do Sul. Pesquisa Agropecuária Gaúcha 2(2):149-154.

6. Battisti R (2013) Épocas de semeadura da cultura da soja com base no risco climático e na rentabilidade líquida para as principais regiões produtoras do Brasil. Dissertação, University of São Paulo

7. Battisti R, Sentelhas PC, Pilau FG, Wollmann CA (2013). Eficiência climática para as culturas da soja e do trigo no estado do Rio Grande do Sul em diferentes datas de semeadura. Ciência Rural 43:390-396. http://dx.doi.org/10.1590/S0103-84782013000300003

8. Battisti R, Sentelhas PC, Boote KJ (2018) Sensitivity and requirement of improvements of four soybean crop simulation models for climate change studies in Southern Brazil. Int. Jour. of Biom, 62(5):823-832. http://dx.doi.org/10.1007/s00484-017-1483-1

9. Berlato MA, Fontana DC (1999) Variabilidade interanual da precipitação pluvial e rendimento da soja no Estado do Rio Grande do Sul. Revista Brasileira de Agrometeorologia, 7(1):119-125

10. Berlato MA, Fontana DC (2003) El Niño e La Niña: Impactos no clima, na vegetação e na agricultura do Rio Grande do Sul: Aplicações de previsões climáticas na agricultura. UFRGS (ed)

11. Calvino PA, Sadras VO (1999) Interannual variation in soybean yield: Interaction among rainfall, soil depth and crop management. Field Crops Research 63:237-246. http://dx.doi.org/10.1016/S0378-4290(99)00040-4

12. Chagas, VBP, Chaffe, PLB (2018) The role of land cover in the propagation of rainfall into streamflow trends. Water Resources Research, 54, 5986-6004.

13. Cirino PH, Féres JG, Braga MJ, Reis E (2015) Assessing the Impacts of ENSO-related weather effects on the Brazilian Agriculture. Procedia Economics and Finance 24:146-155. https://doi.org/10.1016/S2212-5671(15)00635-8 
14. Conab - Companhia Nacional de Abastecimento (2018) Acomp. safra bras. grãos, v. 12 Safra 2017/18 - Décimo segundo levantamento, Brasília, 1-148, ISSN 2318-6852

15. Conab - Companhia Nacional de Abastecimento (2019). Série Histórica das Safras. https://www.conab.gov.br/info-agro/safras/serie-historica-das-safras. Accessed 6 May 2019.

16. Cordeiro A P A, Berlato M A, Alves R de C M (2018). Tendência do índice hídrico sazonal do Rio Grande do Sul e sua relação com El Niño e La Niña. Anuário do Instituto de Geociências 41(3): 216-226. DOI: http://dx.doi.org/10.11137/2018_3_216_226

17. Cunha GR, Haas JC, Dalmago GA, Pasinato A (1998) Perda de rendimento potencial em soja no Rio Grande do Sul por deficiência hídrica. Revista Brasileira de Agrometeorologia 6(1):111119

18. Cunha GR, Haas JC, Maluf JRT, Caramori PH, Assad ED, Braga HJ, Jullo Jr J, Lazzarotto C, Gonçalves S, Wrege M, Brunetta D, Dotto, SR, Pinto HS, Brunini O, Thomé VMR, Zampieri SL, Pasinato A, Pimentel MBM, Pandolfo C (2001) Zoneamento agrícola e época de semeadura para trigo no Brasil. Revista Brasileira de Agrometeorologia 9:400-414

19. Cunha NG da, Silveira RJ da C, Koester E, Oliveira LD de, Alba JMF, Costa FA da, Terres VC, Lopes RT (2010) Estudos de Solos do Município de Iraí. RS. Circular Técnica 104. Embrapa (ed) ISSN 1516-8832

20. Cunha NG da, Silveira RJ da C, Severo CRS, Pinto LFS, Mendes RG, Silva JB da, Duarte LR, Schumacher RL (2005) Estudo de Solos do Município de Encruzilhada do Sul - RS. Circular Técnica 45. Embrapa (ed). ISSN 1516-8832

21. Custodio, M de S (2016) Índice de nebulosidade do estado do Rio Grande do Sul: climatologia e impactos do El Niño Oscilação Sul. Ciência e Natura 38(1):382-392. DOI:10.5902/2179$460 \times 18175$

22. Diniz, F de A, Ramos, AM, Rebello ERG (2018) Brazilian climate normals for 1981-2010. Pesquisa Agropecuária Brasileira. 53(2): 131-143. doi: 10.1590/S0100-204X2018000200001

23. Divisão de Pedologia e Fertilidade do Solo (1962) Ministério da Agricultura. Levantamento de reconhecimento dos solos do estado do Rio Grande do Sul. Primeira etapa. Planalto Riograndense. Pesquisa Agropecuária Brasileira 2:71-209

24. ECR (2017) Ensaio de Cultivares em Rede. http://cultivares.com.br/cultivares2/cultivares.php. Accessed 10 March 2018

25. Fehr WR, Caviness CE (1977) Stages of soybean development. Ames, Yowa: Yowa State University of Science and Technology, Cooperative Extension Service, 11 p. (Special Report, n. 80)

26. Feng S, Hu Q, Qian Q, (2004) Quality control of daily meteorological data in China, 19512000: a new dataset. International Journal of Climatology 24, 853 - 870. 
27. Fontana DC, Berlato MA (1997) Influência do El Niño Oscilação Sul sobre a precipitação do Estado do Rio Grande do Sul. Revista Brasileira de Agrometeorologia 5(1):127-132

28. Gelcer E, Fraisse C, Dzotsi K, Hu Z, Mendes R, Zotarelli L (2013) Effects of El Niño Southern Oscillation on the space-time variability of Agricultural Reference Index for Drought in midlatitudes. Agricultural and Forest Meteorology 174-175: 110-128. http://dx.doi.org/10.1016/j.agrformet.2013.02.006

29. Genro Junior AS, Reinert DJ, Reichert JM, Albuquerque JA (2009) Atributos físicos de um Latossolo Vermelho e produtividade de culturas cultivadas em sucessão e rotação. Ciência Rural 39(1):65-73. http://dx.doi.org/10.1590/S0103-84782009000100011

30. Giarola NFB, Silva AP, Imhoff S (2002) Relações entre propriedades físicas e características de solos da região Sul do Brasil. Revista Brasileira de Ciência do Solo 26:885-893

31. Giménez L, Paredes P, Pereira LS (2017) Water use and yield of soybean under various irrigation regimes and severe water stress. Application of AquaCrop and SIMDualKc Models. Water 9:393-411. http://dx.doi.org/10.3390/w9060393

32. Goldblum D, (2009) Sensitivity of Corn and Soybean Yield in Illinois to Air Temperature and Precipitation: The Potential Impact of Future Climate Change. Physical Geography 30(1):27-42.

33. Grassini P, Torrion J, Cassman K, Yang HS, Specht JE (2014) Drivers of spatial and temporal variation in soybean yield and irrigation requirements in the western US Corn Belt. Field Crops Research 163:32-46. https://doi.org/10.1016/j.fcr.2014.04.005

34. Grassini P, Torrion JA, Yang HS, Rees J, Andersen D, Cassman KG, Specht JE (2015) Soybean yield gaps and water productivity in the Western U.S. Corn Belt. Field Crops Research 179:150163. http://dx.doi.org/10.1016/j.fcr.2015.04.015

35. Grimm AM (2004) How do La Niña events disturb the summer monsoon system in Brazil? Climate Dynamics 22, 123 - 138.

36. Grimm AM (2011) Interannual climate variability in South America: impacts on seasonal precipitation, extreme events, and possible effects of climate change. Stoch Environ Res Risk Assess 25:537-554.

37. Grimm AM, Ferraz SET, Gomes J (1998) Precipitation anomalies in southern Brazil associated with El Niño and La Niña events. Journal of Climate, v. 11, 2863-2880.

38. Grimm AM, Tedeschi RG (2009) ENSO and Extreme Rainfall Events in South America. Journal of Climate 22, 1589-1609.

39. Grimm, AM, Barros VR, Doyle ME (2000) Climate variability in Southern South America associated with El Niño and La Niña events. Journal of Climate, v.13, 35-58.

40. Hargreaves GH, Samani ZA (1985) Reference crop evapotranspiration from temperature. Applied Engineering in Agriculture 1(2):96-99 
41. Iizumi T, Luo JJ, Challinor AJ, Sakurai G, Yokozawa M, Sakuma H, Brown ME, Yamagata T (2014) Impacts of El Niño Southern Oscillation on the global yields of major crops. Nature Communications 5(3712):1-7. http://dx.doi.org/10.1038/ncomms4712

42. Instituto Nacional de Meteorologia (Inmet). Normais Climatológicas do Brasil 1981-2010. Edição digital. Brasilia, 2018. 766p.

43. Letson D, McCullough BD (2001) ENS0 and Soybean Prices: Correlation without Causality Journal of Agricultural and Applied Economics 33(3):513-521.

44. Macedo W (1984). Levantamento de reconhecimento dos solos do Município de Bagé. Documentos. 1. EMBRAPA-UEPAE (ed).

45. Machado FP (1950) Contribuição ao Estudo do Clima do Rio Grande do Sul. Instituto Brasileiro de Geografia e Estatística. Conselho Nacional de Geografia. Serviço Gráfico do Instituto Brasileiro de Geografia e Estatística. Rio De Janeiro. 91p.

46. Maluf, J.R.T.; Caiaffo, M.R.R. (2001) Regiões ecoclimáticas do Estado do Rio Grande do Sul. In: Congresso Brasileiro De Agrometeorologia, 12. / Reunião Latino-Americana De Agrometeorologia, 3., 2001, Fortaleza. Água e agrometeorologia no novo milênio 151-152.

47. MAPA - Ministério da Agricultura, Pecuária e Abastecimento (2018). Portarias de zoneamento agrícola de risco climático. http://www.agricultura.gov.br/assuntos/riscos-seguro/riscoagropecuario/portarias/safra-vigente/rio-grande-do-sul. Accessed 15 August 2018

48. Martorano LG (2007) Padrões de resposta da soja a condições hídrica do campo sistema soloplanta-atmosfera observados no campo e simulados no sistema de suporte à decisão DSSAT. Dissertação, Universidade Federal do Rio Grande do Sul.

49. Matzenauer R, Radin B, Maluf JRT (2017) O fenômeno ENSO e o regime de chuvas no Rio Grande do Sul. Agrometeoros 25(2):323-331

50. Matzenauer, R, Radin, B, Cargnelutti Filho, A (2018). Rendimento de grãos de soja e de milho, no Rio Grande do Sul, não difere entre eventos El Niño Oscilação Sul. Agrometeoros 26(1): 123129. DOI: http://dx.doi.org/10.31062/agrom.v26i1.26376

51. Melo RW de, Fontana DC, Berlato, MA (2004) Indicadores de produção de soja no Rio Grande do Sul comparados ao zoneamento agrícola. Pesquisa Agropecuária Brasileira 39(12):1167-1175

52. Nicoloso R da S, Amado TJC, Schneider S, Lanzanova ME, Girardello VC, Bragagnolo JE (2008) Eficiência da escarificação mecânica e biológica na melhoria dos atributos físicos de um latossolo muito argiloso e no incremento do rendimento de soja. Revista Brasileira de Ciência do Solo,32:1723-1734. http://dx.doi.org/10.1590/S0100-06832008000400037

53. Nielsen DC, Ma L, Ahuja LR, Hoogenboom G (2002) Simulating soybean water stress effects with RZWQM and CROPGRO models. Agronomy Journal 94: 1234-1243 
54. NOAA (2018) National Weather Service. Cold \& warm episodes by season. origin.pcp.ncep.noaa.gov/products/analysis_monitoring/ensostuff/ONI_v5.php. Accessed 26 April 2018

55. Nóia Júnior R de S, Sentelhas PC (2019) Soybean-maize off-season double crop system in Brazil as affected by El Niño Southern Oscillation phases. Agricultural Systems, 173:254-267. https://doi.org/10.1016/j.agsy.2019.03.012

56. Nóia Júnior, R de S, Fraisse, CW, Karrei, MAS, Cerbaro, VA, Perondi, D (2020) Effects of the El Niño Southern Oscillation phenomenon and sowing dates on soybean yield and on the occurrence of extreme weather events in southern Brazil. Agricultural and Forest Meteorology 290:108038. https://doi.org/10.1016/j.agrformet.2020.108038

57. Nunes MCM, Cassol EA (2008) Estimativa da erodibilidade em entressulcos de latossolos do Rio Grande do Sul. Revista Brasileira de Ciência do Solo, 32:28392845. http://dx.doi.org/10.1590/S0100-06832008000700030

58. Philander, S.G.H., 1983. El Niño Southern Oscillation phenomena. Nature 302, 295-301. https://doi.org/10.1038/302295a0.

59. Pilau FG, Battisti R, Dalmago GA (2018) Requerimento de irrigação suplementar e eficiência climática para a cultura da soja no Rio Grande do Sul. Agrometeoros 26(2):317-325. DOI: http://dx.doi.org/10.31062/agrom.v26i2.26392

60. Pötter RO, Hochmüller DP (1980) Levantamento detalhado de área piloto para conservação de solos no município de Ibirubá. RS. Rio de Janeiro. Boletim Técnico. 68. EMBRAPA/SNLCS (ed).

61. Pscheidt I, Grimm A M (2009). Frequency of extreme rainfall events in Southern Brazil modulated by interannual and interdecadal variability. International Journal of Climatology 29: 1988-2011.

62. Purcell LC, Specht, JE (2004) Physiological traits for ameliorating drought stress. In: Boerma HR, Specht JE (eds), Soybeans: Improvement, production, and uses, 3rd ed. Agron. Monogr. 16. ASA, CSSA, and SSSA, Madison, WI. pp 569-620. http://dx.doi.org/10.2134/agronmonogr16.3ed.c12

63. Puchalski LA (2000) Efeitos associados ao El Niño e La Niña na temperatura média, precipitação pluvial e no déficit hídrico no Estado do Rio Grande do Sul. 83p. Dissertação (Mestrado) - Universidade Federal do Rio Grande do Sul, Porto Alegre.

64. Reek T, Doty, SR, Owen, TW (1992) A deterministic approach to the validation of historical daily temperature and precipitation data from the Cooperative Network. Bulletin of the American Meteorological Society 73, $753-762$. 
65. Reichert JM, Albuquerque JA, Kaiser DR, Reinert DJ, Urach FL, Carlesso R (2009) Estimation of water retention and availability in soil of Rio Grande do Sul. Revista Brasileira de Ciência do Solo 33:1547-1560. http://dx.doi.org/10.1590/S0100-06832009000600004

66. Reinert DJ, Albuquerque JÁ, Reichert JM, Aita C, Andrada MMC (2008) Limites críticos de densidade do solo para o crescimento de raízes de plantas de cobertura em Argissolo Vermelho. Revista Brasileira de Ciência do Solo, 32:1805-1816. http://dx.doi.org/10.1590/S010006832008000500002

67. Secco D, Da Ros CO, Fiorin JE, Pautz CV, Pasa L (1997) Efeito de sistemas de manejo nas propriedades físicas de um latossolo vermelho-escuro. Ciência Rural 27(1):57-60. http://dx.doi.org/10.1590/S0103-84781997000100011

68. Secco D, Reinert DJ, Reichert JM, Ros CO da (2004) Produtividade de soja e propriedades físicas de um latossolo submetido a sistemas de manejo e compactação. Revista Brasileira de Ciência do Solo 28:797-804. http://dx.doi.org/10.1590/S0100-06832004000500001

69. Shafer MA, Fiebrich CA, Arndt DS, Fredrickson SE, Hughes TW, (2000) Quality assurance procedures in the Oklahoma Mesonet. Journal of Atmospheric and Oceanic Technology 17, 474494.

70. Silva AF, Sediyama T, Borém A (2015). Exigências edafoclimáticas, in: Soja do Plantio à Colheita. UFV, Viçosa, pp. 54-65.

71. Streck N A, Rosa H T, Walter L C, Bosco L C, Lago I, Heldwein A B (2008). O fenômeno El Niño Oscilação Sul e a variabilidade interanual da evaporação do tanque Classe A e da umidade relativa do ar em Santa Maria, RS. Ciência Rural (38)5:1452-1455.

72. Tedeschi, RG, Grimm AM, Cavalcanti IFA, (2015) Influence of Central and East ENSO on extreme events of precipitation in South America during austral spring and summer. International Journal of Climatology 35, 2045 - 2064.

73. Thornthwaite CW, Mather JR (1955) The water balance. Centerton, NJ: Drexel Institute of Technology - Laboratory of Climatology. Publications in Climatology, vol. VIII, n.1

74. Van Ittersum MK, Cassman KG, Grassini P, Wolf J, Tittonell P, Hochmand Z (2013) Yield gap analysis with local to global relevance - A review. Field Crops Research 143:4-17. https://doi.org/10.1016/j.fcr.2012.09.009

75. Vieira ML, Klein VA (2007) Propriedades físico-hídricas de um latossolo vermelho submetido a diferentes sistemas de manejo. Revista Brasileira de Ciência do Solo 31:1271-1280. http://dx.doi.org/10.1590/S0100-06832007000600006

76. World Meteorological Organization (2008) Guide to Meteorological Instruments and Methods of Observations. WMO-No.8, Geneva, Switzerland. 
77. Zalamena $\mathbf{J}$ (2008) Impacto do uso da terra nos atributos químicos e físicos de solos do rebordo do Planalto - RS. Dissertação. Universidade Federal de Santa Maria.

78. Zanon AJ, Streck NA, Grassini P (2016) Climate and management factors influence soybean yield potential in a subtropical environment. Agronomy Journal 108(4):1447-1454. http://dx.doi.org/10.2134/agronj2015.0535

79. Zanon, AJ, Winck, JEM, Streck, NA, Richter, GL, Rocha, TSM, Cera, JC (2015) Development of soybean cultivars as a function of maturation group and growth type in high lands and in lowlands. (In Portuguese, with English abstract.) Bragantia 74:400-411. doi:10.1590/16784499.0043 
Figures
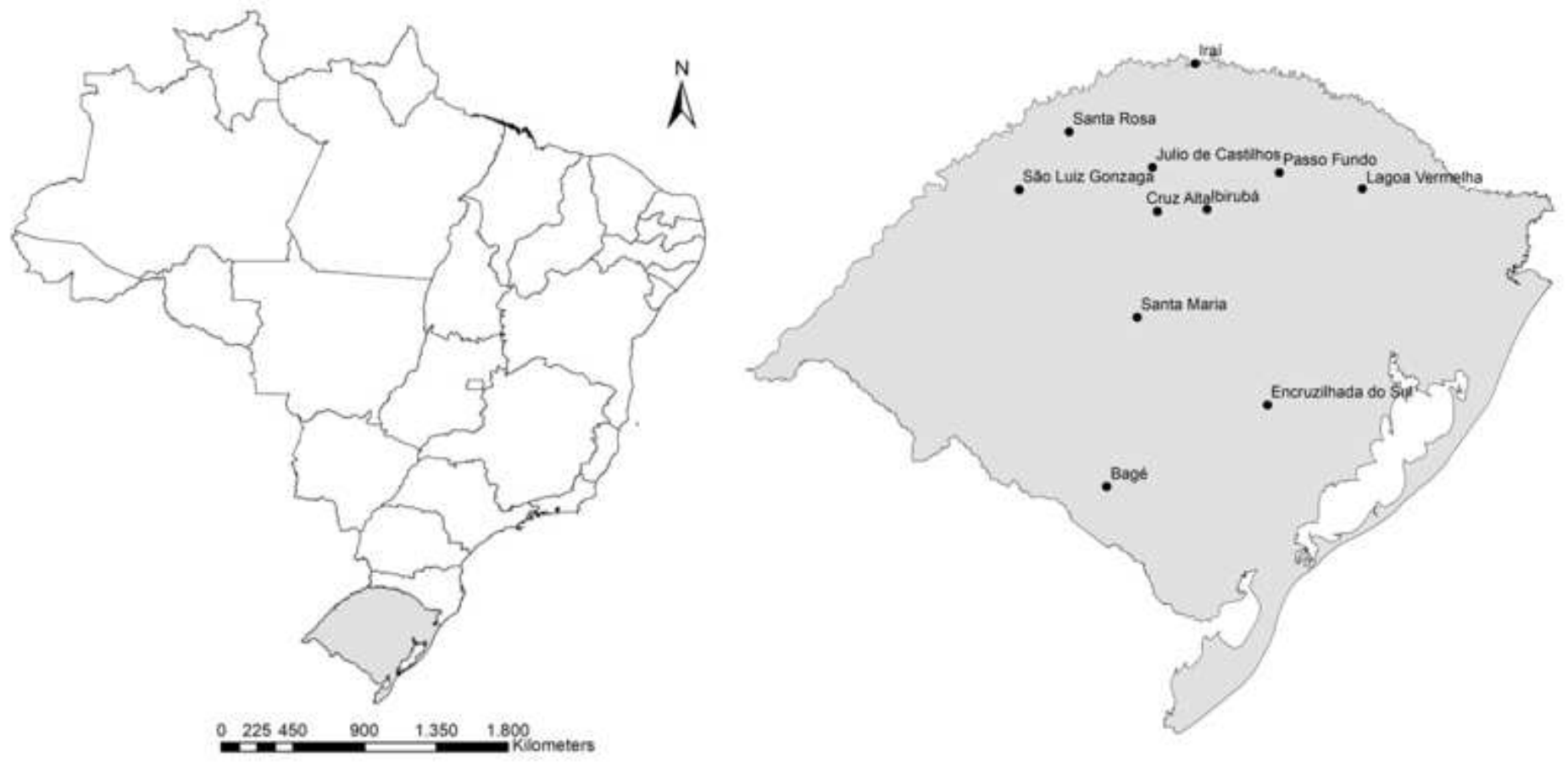

Figure 1

Location of the State of Rio Grande do Sul - Brazil, and distribution of weather stations considered in the analyzes within the State.

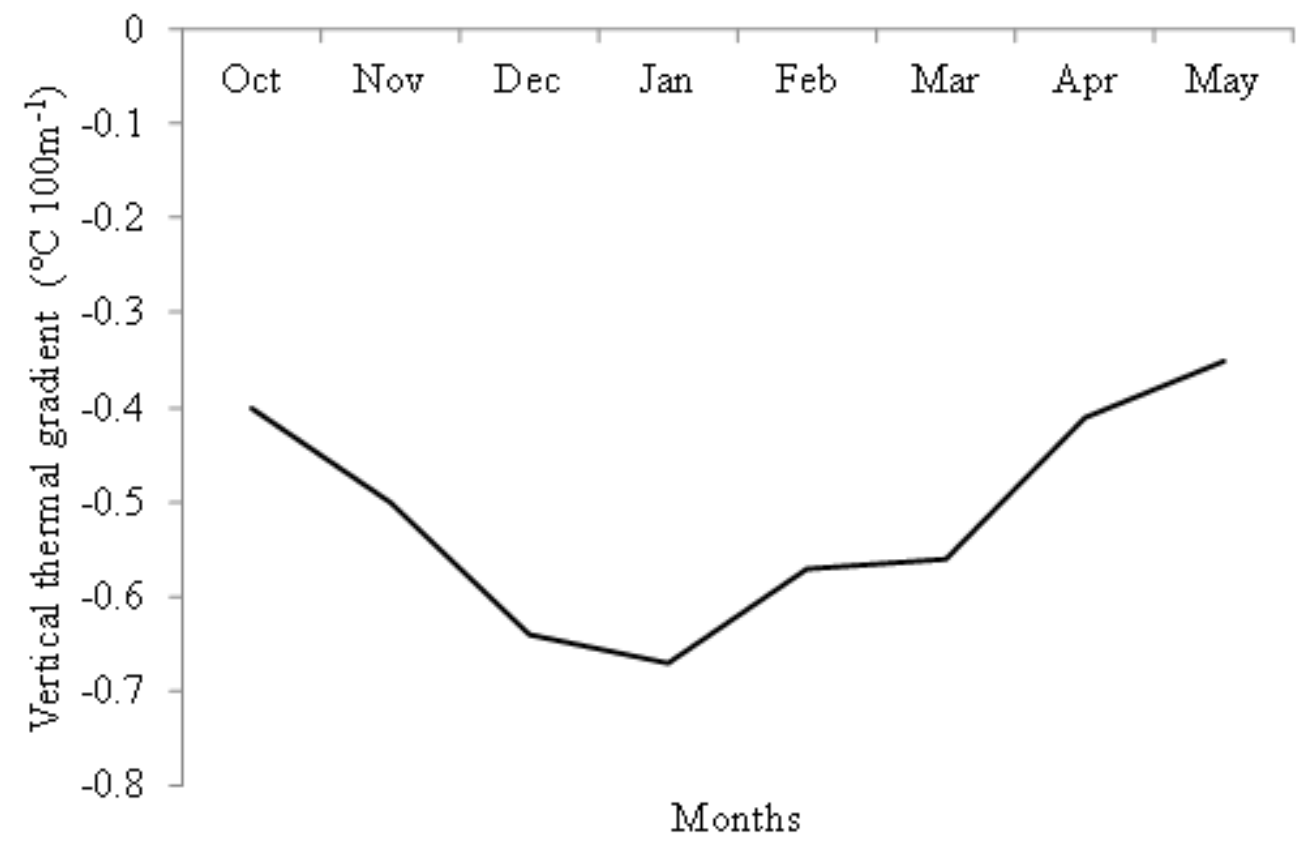

Figure 2 
Vertical thermal gradient $\left({ }^{\circ} \mathrm{C} 100 \mathrm{~m}-1\right)$ from October to May among all weather stations.

\section{Cluster A}

Cluster B
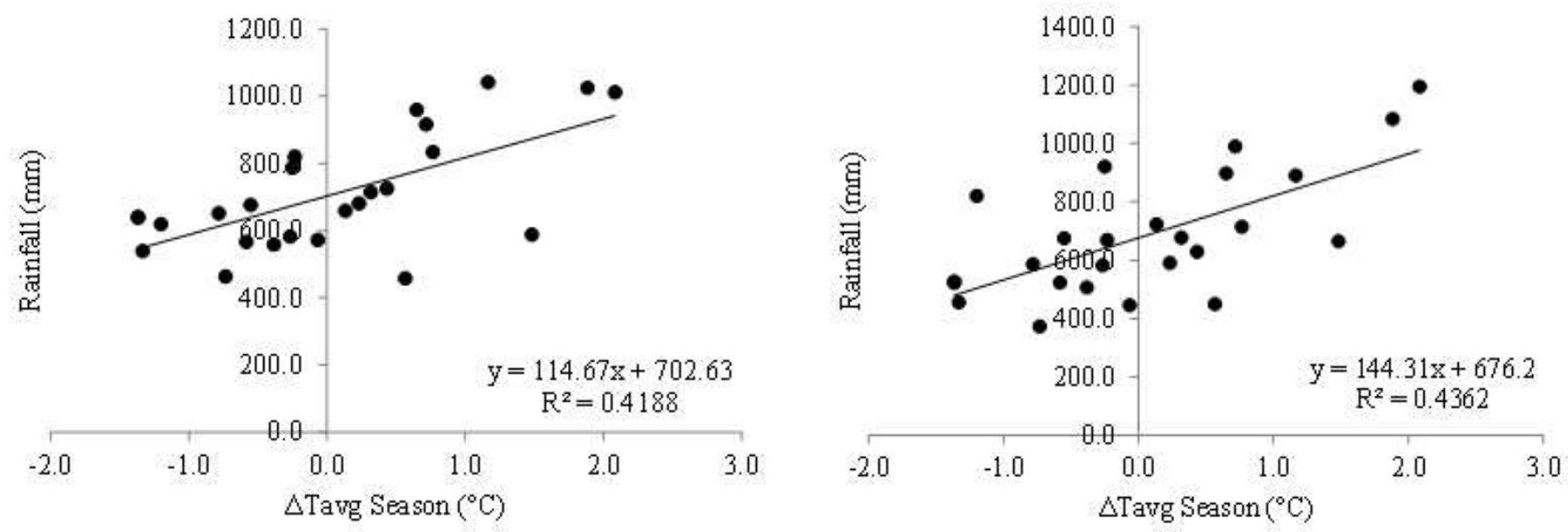

Cluster C

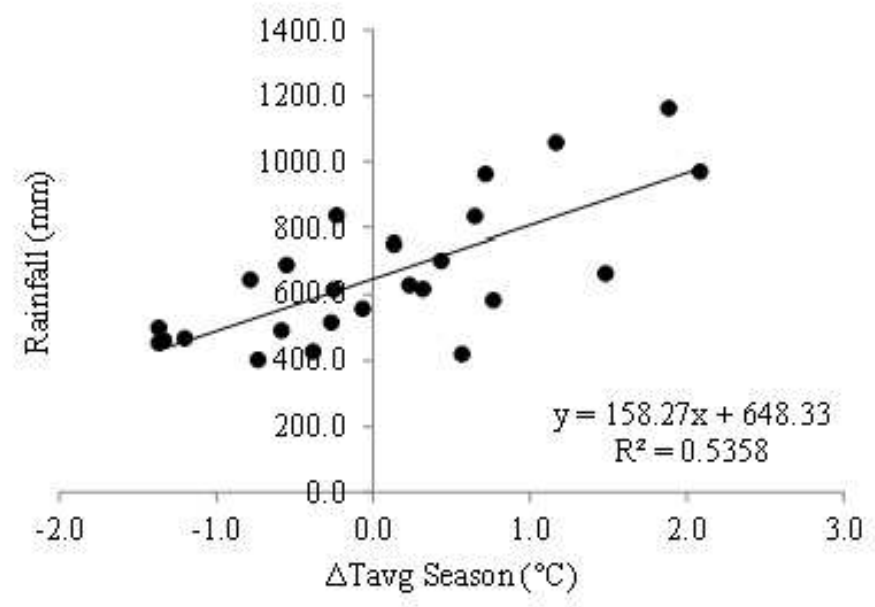

Figure 3

Relationship between mean cumulative rainfall $(\mathrm{mm})$ and mean temperature deviation of the Central Equatorial Pacific Ocean Surface $\left({ }^{\circ} \mathrm{C}\right)$ (OND to MAM seasons). 


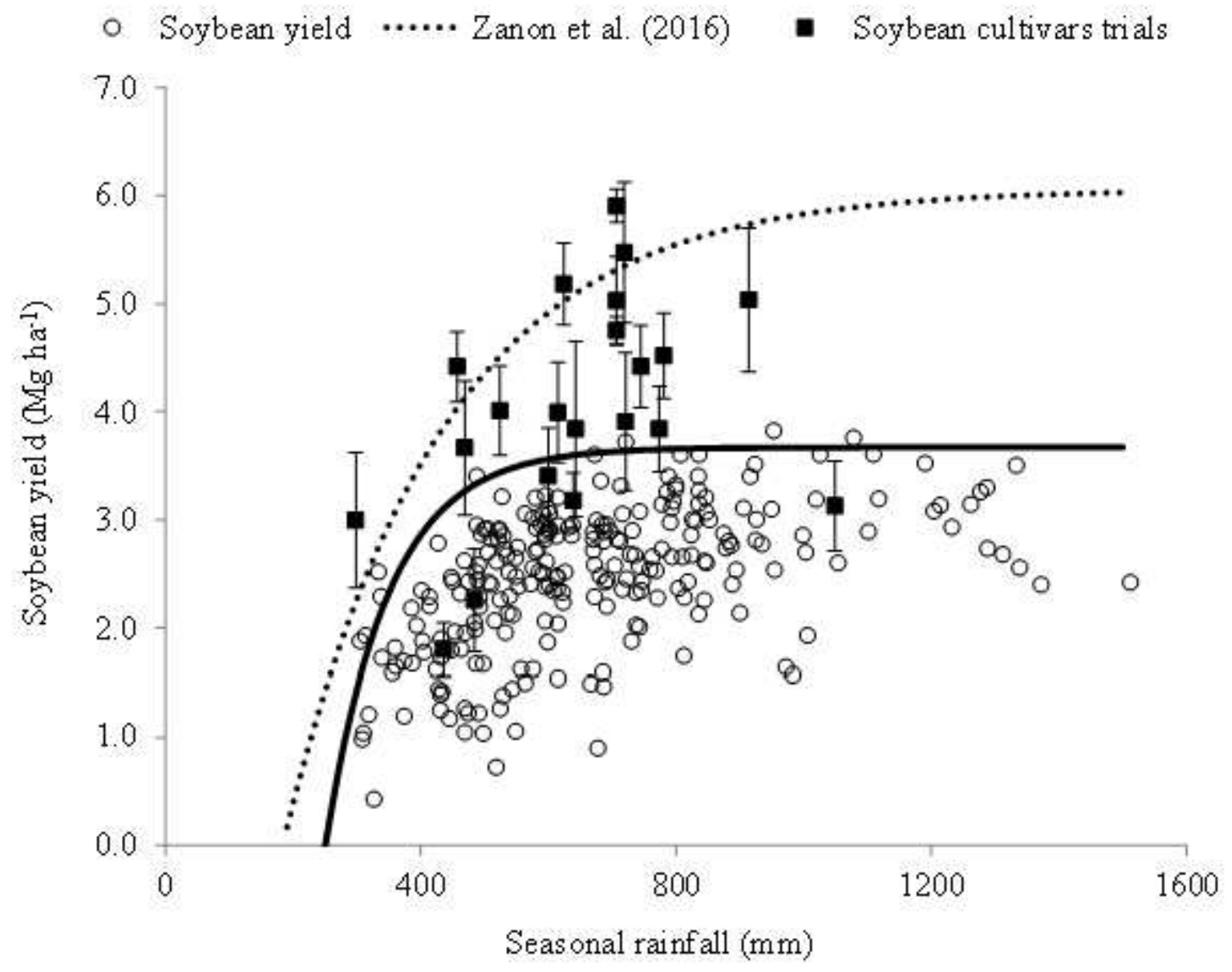

Figure 4

Soybean yield plotted against seasonal rainfall, boundary layer for attainable yield ( $\mathrm{Yw}$ ) and soybean yield data from cultivars trials. 
Cluster A

- Neutral El El Niño $\Delta$ La Niña

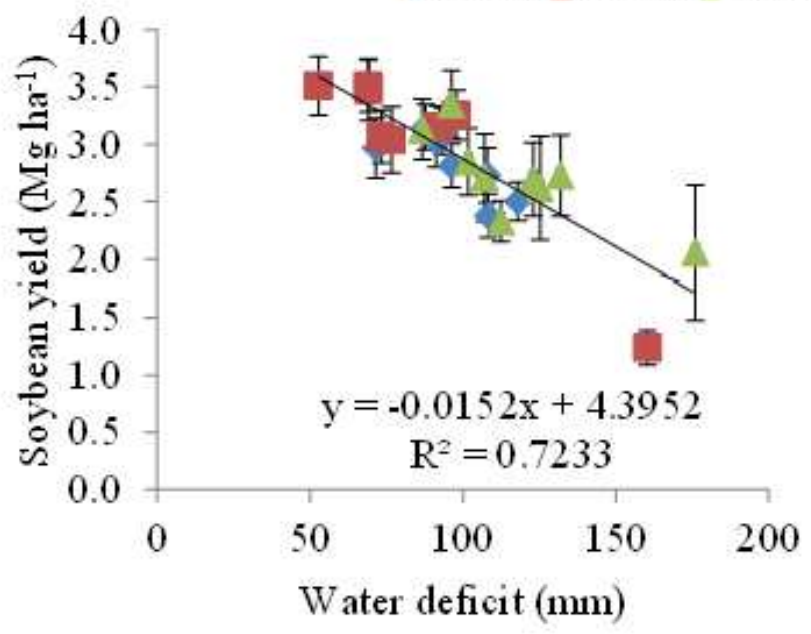

Cluster B

- Neutral al El Niño A La Niña

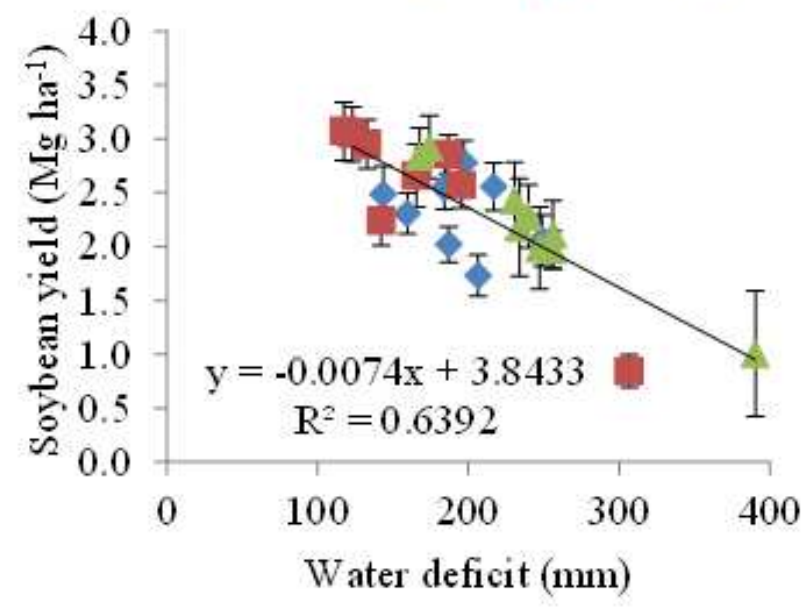

\section{Cluster C}

- Neutral El Niño A La Niña

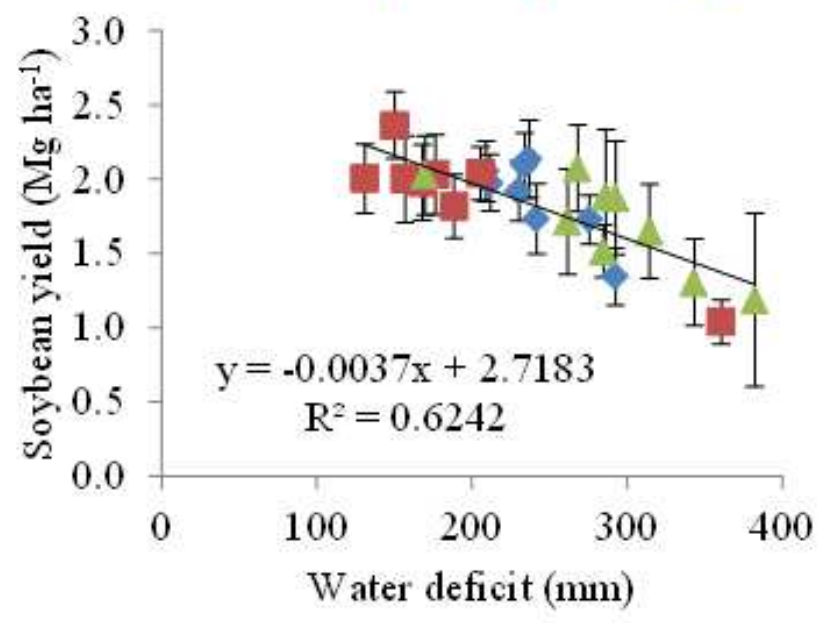

Figure 5

Relationship between soybean yield and water deficit $(\mathrm{mm})$ for different ENSO phases (Neutral, El Niño and La Niña) for Clusters A, B and C. 